\title{
De Estados Unidos, Reino Unido e Islândia ao Brasil: Um estudo tradutológico da Prosa éddica ao português
}

Thais Gomes Trindade ${ }^{1}$

Resumo: A partir de análises tradutológicas de cinco traduções à luz da teoria desconstrutivista, esse trabalho visa preencher a lacuna informativa quanto à chegada da Edda em prosa de Snorri às linguas lusófonas, provendo o público acadêmico ou não de informações detalhadas. O público pode ser provido de informações estilísticas e de conteúdo, enquanto ainda pretende-se apresentar possiveis novos mares à pesquisa ou produção acadêmica sobre o tema.

Palavras-chave: Prosa éddica, Snorri, português, estudo tradutológico.

\section{Estabelecendo o caminho a navegar}

Usualmente as primeiras literaturas a se estabelecerem com uma cultura são mitológicas; narrativas a contar um tempo de criação do cosmos. Nota-se isso na cultura grega com textos primordiais que refletem essa tradição oral, como a Ilíada. Porém, cabe notar que essa definição não se restringe a essa cultura, sendo frequente em outras, como a escandinava.

1 Thais Gomes Trindade é Mestre em Letras Estrangeiras e Tradução pela Universidade de São Paulo. Seu interesse de pesquisa volta-se à área de tradução, línguas e literatura. Teve um artigo publicado no Blog do Núcleo de Estudos Vikings e Escandinavos em 2018 e apresentou seu então projeto de mestrado no VI Colóquio de Estudos Vikings e Escandinavos na Universidade Federal da Paraíba no mesmo ano. Tem dois artigos sobre tradução publicados: um pela revista Revista Yamp (2015) e outro pela revista Rónai (2014). Em 2015, durante um intercâmbio, contribuiu com um trabalho sobre literatura nórdica e Tolkien no Medieval Studies Student Association Colloquium da Universidade do Novo México. Colaborou por duas edições como revisora à revista Yanp. 
O estabelecimento desta cultura se dá no começo do primeiro milênio após Cristo, período da Era de Ferro escandinava, iniciada por volta de 500-400. Daí se tem notícia das primeiras inscrições rúnicas, mas só no final do período entre 600-800, e com inúmeras relações com outros povos, as línguas escandinavas se estabeleceram.

Os reinos escandinavos se estabelecem entre os séculos IX e X, período em que a Islândia é colonizada. Durante esse período a mitologia nórdica é passada oralmente - uma tradição que, mesmo após a cristianização da Islândia, por volta do ano 1000, se manteve, preservando naquele lugar as histórias dos deuses nórdicos. As tradições orais escandinavas se mantiveram vivas com a escrita e outros registros feitos por cristãos. Tem-se notícia de narrativas éddicas em poesia, 35 poemas da Idade Média, que formam a conhecida "Edda poética", registrada por volta de 1280.

No mesmo século, atribui-se ao homem público Snorri Sturluson a autoria da Edda em prosa, um registro da origem, da destruição e da reconstrução do cosmos a partir da mitologia nórdica, com a intenção de apresentar aos novos escaldos a origem das metáforas usadas por eles.

De mitologia como narrativas primordiais, a mitologia nórdica passou a influenciar novos estudos acadêmicos, novas criações literárias, cinematográficas e de outras artes, como a pintura, chegando a inspirar a apresentação de Thor, um deus, como super-herói pela companhia Marvel.

Suas releituras e menções feitas ao longo do tempo mostram como ainda é atual e interessante para um público bastante diverso. Mas, apesar do interesse pelo tema, poucos estudos são voltados a essa área que começa a se desenvolver no Brasil. Dessa forma, pouca informação se tem sobre traduções da Edda ao português.

Assim como a mitologia, traduções são antigas. Da Antiguidade à Contemporaneidade, diversas teorias tradutórias e estratégias foram vistas. A obra de Susan Bassnett-McGuire, Translation Studies (1988), é uma das mais importantes a discutir a área de estudos da tradução antes de sua organização como disciplina.

Essa discussão reconhece a tradução como produto que vem de uma interpretação feita de uma língua-fonte a uma língua-alvo com o propósito de aproximar ambas e manter a estrutura da língua-fonte o máximo possível, mas não a ponto de as estruturas da língua-alvo serem distorcidas (BASSNETT, 1988, p. 2). Por isso é necessário o reconhecimento de hábitos, culturas e contextos de uma comunidade como influenciadores de traduções, não apenas a língua ou a linguagem. Apesar 
de alguns argumentarem pela impossibilidade da tradução, nota-se que traduções são sempre possíveis, mas, acima de tudo, frutos interpretativos.

Por séculos a ideia de equivalência em tradução passou por mudanças. $O$ mesmo pode ser dito quanto às noções de intraduzível, perda e ganho. Porém, como afirmado por Bassnett (1988) e Arrojo (1986), a função da tradução não seria a de atingir a perfeição, mas de alinhar-se a um projeto criativo e interpretativo advindo do tradutor.

Apesar de haver desenvolvimento de traduções desde a Antiguidade, no que concerne o ato tradutório em si, somente no século XV aparecem as primeiras teorias. De John Dryden, no século XVII, vêm as descrições de tradução como metáfrase (palavra por palavra, linha a linha); paráfrase (sentido por sentido); e imitação (abandono da fonte em detrimento da intenção do tradutor) (BASSNETT, 1988, p. 60).

Do Período Vitoriano deriva a preocupação com atualização de um texto, com a aproximação de uma obra a seu público leitor levando em consideração seu lugar e tempo. A partir de então é dada maior atenção ao status, à funcionalidade e à sistematização acadêmica da tradução.

As propostas de Bassnett, em que mostra como nem tudo terá equivalente em uma língua, sendo necessário, certas vezes, se não muitas, ater-se às funções de um texto muito mais do que a "nomes", nos direcionam a uma teoria desconstrutivista, como a de Arrojo (1986), que, diferentemente de Eugene Nida, não vê a tradução como um transporte de sentidos e significados entre duas línguas, ou representação fiel de um objeto estável, mas sim como um "palimpsesto", "texto que se apaga, em cada comunidade cultural e em cada época, para dar lugar a outra escrita (ou interpretação, ou leitura, ou tradução) do "mesmo texto"' (p. 23-24).

Para Aubert (1994), o ponto de partida no que diz respeito à fidelidade na tradução deve ser a "mensagem efetiva", apreendida pelo tradutor no ato de leitura, interpretação particular e individual, e um "compromisso de fidelidade com as expectativas, necessidades e possibilidades dos receptores finais" a partir de sua visão particular, não um mero transporte linguístico (p. 75-76). Fidelidade, para Aubert (1994), seria ainda a "busca e o estabelecimento de um locus de equilíbrio entre o centrífugo (a tendência à alteridade) e o centrípeto (a procura pela identidade)", cabendo ao tradutor encontrar esse ponto de equilíbrio e expô-lo ao seu leitor a partir de sua intenção tradutória (p. 75-76). Isto é, Aubert (1994) argumenta por um balanço entre as forças de estrangeirização e domesticação. 
Pela Teoria do Escopo (Skopostheorie), motivadora do funcionalismo, a tradução se estabelece pelo "propósito" comunicativo, agentes envolvidos na situação comunicativa e na situação em questão (NORD, 1997:1), advindo das discussões sobre "equivalência linguística", que se prestava ao que devia ser "preservado" do texto original (NORD, 1997:7). Ao ponto que a "equivalência" se mostrava ineficiente a contextos em que a "compreensão" seria o propósito primeiro, Reiss desenvolve uma teoria focada na "relação funcional" entre originais e tradução (NORD, 1997:9). Isto é, adaptações de músicas de uma língua a peça teatral, em outra língua, seria um exemplo de como a função do texto-alvo seria mais importante à tradução do que necessariamente a equivalência cega ao original (NORD, 1997:9).

Esse desenvolvimento da teoria tradutória abre espaço à maior consideração do projeto tradutório em cada ato de tradução, seja por vias mais ou menos "estrangeirizantes", isto é, a opção de adotar mais das qualidades e características da cultura ou língua-fonte ou de trazer o original o mais próximo possível à cultura-alvo. Essa escolha seria do tradutor.

Porém esses conceitos de domesticação e estrangeirização, são teorizados por Venuti (1995:20), respectivamente, como uma "redução do etnocentrismo de um texto estrangeiro aos valores culturais de uma língua-alvo, trazendo o autor para casa" e como uma "pressão de desvio ético àqueles valores [da língua/cultura-meta] para registrar a diferença linguística e cultural do texto estrangeiro, levando o leitor ao estrangeiro". Apesar de apresentar as duas possibilidades, critica a segunda pela contingência de produção de uma experiência de leitura "alienígena" na prática de afastamento dos "cânones literários domésticos" (VENUTI, 1995:20).

Ainda que, de acordo com Aubert (1994) e Nord (1997), a fidelidade e os projetos tradutórios sejam variáveis, não deixa de ser relevante a observação das dinâmicas que subjazem a esses processos, valendo-se esse trabalho das observações de Antoine Berman em "Translation and the trials of the foreign language" para o estudo tradutológico e o entendimento do impacto da tradução em cada ato. Berman propõe que a tradução pode ser entendida como o resultado de um trabalho de exposição de uma "estrangeiridade" de um texto a um "estrangeiro", seja ele um leitor ou uma língua (BERMAN. Apud VENUTI, 2000, p. 284). Embora muitos teóricos vejam essa dinâmica com maus olhos, Berman vê a complexidade da tradução como "trial", situação em que o "exilamento" do original de seu meio rumo a um outro, tanto linguístico quanto cultural, torna-se uma oportunidade de revelação da própria obra em questão, não apenas de distanciamento (BERMAN. Apud VENUTI, 2000, p. 284). 
Porém, ao analisar essa dinâmica torna-se inegável a existência de certas tendências. Uma vez que Berman advoga uma tradução estrangeirizante, ele tenderá a avaliar as traduções pela sua estrangeiridade, ao que vê domesticações negativamente, dado o termo "tendências deformacionais". Para Berman, seriam doze: "racionalização", "clarificação", "expansão", "enobrecimento e popularização", "empobrecimento qualitativo", "empobrecimento quantitativo", "destruição de ritmos", "destruição de cadeias subjacentes de significação", "destruição de padrões linguísticos", "destruição de cadeias vernáculas ou sua exotização", "destruição de expressões idiomáticas ou não" e "anulação da superimposição de línguas" (BERMAN. Apud VENUTI, 2000, p. 284). Essas tendências manifestar-se-ão, respectivamente, na alteração da pontuação e de sua influência sobre a tradução, na clarificação de termos ou expressões, sendo que ambos levam à expansão linguística do texto, que ainda pode ser acompanhada pelo enobrecimento ou pela popularização do estilo, no empobrecimento do tom ou da iconicidade em função dos termos ou das expressões adotados, no empobrecimento lexical advindo da expansão, na destruição do ritmo individual da obra independentemente de seu gênero, na destruição de cadeias de significado promovidas por certas escolhas paradigmáticas do texto, na destruição de padrões linguísticos, na destruição de expressões ou estruturas vernáculas, que ainda podem passar a "exótico" a depender das estratégias adotadas, na destruição de expressões idiomáticas ou não e na "anulação" da relação entre as línguas envolvidas (BERMAN Apud VENUTI, 2000, p. 288-297).

Vale ressaltar, porém, que alinho minha análise às tendências desconstrutivistas e da Teoria do Escopo no que diz respeito a entender que cada tradutor terá um projeto diferente e, como tal, adotará uma postura domesticadora ou estrangeirizante, ao que não busco validar apenas uma. Porém, ao que diz respeito às tendências deformadoras, elas são formas válidas de avaliar como uma domesticação se dá em determinado contexto, ao que não deixarei de levá-la em consideração na minha análise. À luz dessas linhas teóricas, procurarei analisar como cada tradução da Edda em prosa ao português serviu a seus próprios propósitos e projetos particulares, avaliando estratégias, particularidades, desafios e benefícios ao público também dialogando com as tendências deformacionais de Berman. Nota-se que a origem dessa pesquisa remonta às reuniões e aulas de Mitologia Viking tidas no primeiro semestre de 2015 na University of New Mexico (UNM), Estados Unidos, e à intenção de divulgação e análise de traduções da Edda em prosa à língua portuguesa, uma pesquisa nascida sob a orientação do Professor John Lindow e continuada com o apoio do professor John Milton da Universidade de São Paulo (USP). 
Essa análise tradutológica da Edda dar-se-á pela comparação das traduções em português com as traduções ao inglês de Anthony Faulkes (1995; 2012), alinhando-se com o material mais usado pelos tradutores estudados: as traduções inglesas. Vale notar que, como aponta Aubert (1994), "na tradução de textos cujos originais remontam a um ou mais séculos, manifestam-se diferenças diacrônicas marcantes, não apenas de natureza linguística, como também de natureza referencial, de visão de mundo". Sabendo dessa singularidade, o anacronismo e a distância cultural, espacial e temporal, a presente análise não terá por finalidade sua problematização, mas sim o reconhecimento de cada projeto e suas contribuições aos leitores de língua portuguesa na busca por conhecimento da mitologia nórdica, relevando alguns anacronismos e se atendo à entrega de sentidos, mitos e cultura ao público leitor quando não se qualificarem quanto às tendências deformacionais. As traduções a serem analisadas são de 1993, por Marcelo Magalhães, 2008 e 2013, por Marcio Moreira, e de 2013 e 2014, por Artur Avelar. Não foram encontradas outras traduções, nem recentes e nem antigas, chegando a ter sido consultada a obra Bibliography of the Eddas, de Halldór Hermannsson (1920). Embora no início da pesquisa a tradução de Avelar (2013) estivesse disponível, mais recentemente essa obra tornou-se indisponível, tendo-se sido feito uso de exemplar obtido anteriormente a esse fato.

\section{Mares de textos: conhecendo as Eddas de Snorri ao português}

\section{Marcelo Magalhães Lima}

A primeira tradução da Edda de Snorri para o português data de 1993, impressa e publicada pela editora Numen, traduzida, apresentada e anotada por Marcelo Magalhães Lima. Em "Tradução e notação" tem-se a explicação das estratégias fonéticas utilizadas pelo tradutor. Embora suas explicações estratégicas possam levar o leitor a inferir que sua tradução tivesse sido feita do islandês antigo, a advertência "embora ciente das dificuldades que poderão ser encontradas por aqueles não versados em islandês antigo, optei por preservar a grafia dos nomes próprios encontrados na obra", a ficha catalográfica indica ao leitor tratar-se de uma tradução feita a partir do inglês, "Tradução de: The Prose Edda of Snorri Sturluson (Snorraedda)" (LIMA, 1993, p. 23; 2).

Ainda na seção anteriormente citada o tradutor elenca os textos que utilizou como apoio, sendo eles: The Prose Edda, por J. I. Young (Berkeley-L.A.-London, 1954), Textos 
Mitológicos de las Eddas, por Enrique Bernardez (Madrid, 1987) e Snorra Edda, por Eugen Mogk (Helsinki, 1854 [sic]). As traduções da Edda poética usadas como apoio principalmente para os poemas citados em Gylfaginning, posto que Skáldskaparmál traz apenas um trecho nesta edição, são as de F. Genzmer (Jena, 1912), L. Hollander (Texas, 1928), W. Ranisch (Leipzig, 1865), F. Jónsson (Halle, 1888) e A. Heusler (Estrasburgo, 1902). A tradução de Marcelo Magalhães contou ainda com o estudo da Völuspá de Eugen Mogk (Helsinki, 1854) [sic] e o estudo de Ivar Lindquist sobre Háva Mál (Lung, 1956). Nesse trecho da apresentação tradutória há três imprecisões. A primeira é a data de publicação da tradução de Eugen Mogk, nascido em 1854 - a publicação remontaria, na verdade, a 1924, conforme citado por John Lindow em Norse Mythology: A Guide to Gods, Heroes, Rituals and Beliefs (2001), e não a 1854, tendo-se a mesma incorreção quanto ao estudo de Mogk sobre a Völuspá. Outro detalhe que pode confundir o leitor é o da data de publicação da tradução de Wilhelm Ranisch, que corresponde a 1903, e não a 1856; por último, tem-se a separação do nome Hávamál em duas palavras.

Esta tradução de 1993 é formada por três seções: "Prólogo”, “Gylfaginning” e "Skáldskaparmál”, sendo que apenas as duas primeiras foram traduzidas integralmente. É, ainda, antecedida por introduções sobre os germanos e vikings, sobre a Islândia, sobre os autores das Eddas, sobre a Edda em prosa de Snorri Sturluson, sobre a influência cristã nos trechos éddicos, sobre o debate da origem do vocábulo “edda”, sobre a tradução e as notas, sobre a bibliografia, sobre as notas de pronunciação e sobre as abreviações dos poemas.

A tradução é acompanhada por notas explicativas de rodapé, através das quais o leitor pode encontrar versões diferentes para as histórias relacionadas às divindades e a seus mitos, entre outras informações, como a origem e as características de Njörd, que, segundo Lima, compartilha semelhanças com Nerthus (deusa apresentada por Tácito) no que diz respeito às suas ritualizações. Lima afirma que ambos provavelmente originam-se de uma mesma divindade hermafrodita indo-europeia (LIMA, 1993, p. 77, nota 53). Há notas sobre passagens supostamente adicionadas posteriormente à Edda de Snorri, como na página 59 - "Aqui encontramos uma contradição relevante entre o Prólogo e Gylfaginning. No primeiro Pórr é apresentado como o progenitor da estirpe divina e, no segundo, Óðinn. Hoje, porém, considera-se que o Prólogo dificilmente foi obra de Snorri e, sim, uma edição cristã posterior ao seu trabalho”. Além disso, Marcelo Magalhães permite ao leitor conhecer mais sobre a cultura nórdica por referências à mesma na Edda, por exemplo ao mencionar o arco e a flecha como utensílios comumente utilizados nessa comunidade. $O$ tradutor também permite ao leitor conhecer as teorias que relacionam o surgimento dos substantivos para os dias da semana em algumas línguas em relação aos deuses mitológicos, como na nota 59 (Idem, 1993, p. 79), em que explica que Friday teria surgido de um epíteto de Frigg, Freitag, e não da divindade Freyia - "Erroneamente, o nome da deusa Freyja é considerado a origem do nome do sexto dia da semana em alemão moderno, freitag, e em inglês moderno, friday. A explicação correta, porém, é a de que esses estão relacionados ao nome Frija, epíteto da deusa Frigg, identificada com a deusa latina Vênus". 
Uma inadequação teórica é entender o nome de Loki como derivado de fogo em islandês, lopt, por extensão, deus do fogo. Embora Magalhães afirme isso com base na teoria de H. Fischer, segundo John Lindow, em reuniões acadêmicas sobre esta pesquisa (2015), não haveria evidência para sustentar o argumento (LIMA, 1958, p. 8). Johnni Langer (2015, p. 281), por outro lado, aponta a etimologia do nome como discutível, mas impassível de consenso quanto a seu significado.

Segundo Magalhães, Skáldskaparmál consistiria apenas de passagens mitológicas, seguindo a tradição tradutória do referido texto (LIMA, 1993, p. 20). Não se sabe, porém, a que tradição tradutória estaria referindo-se, uma vez que a obra de J. I. Young (1954), utilizada por Magalhães, vai mais longe que a do último, alcançando o trecho em que o kenning de Hiadnings é explicado como referente a "batalha" e originário da história do Rei Hogni, estendendo-se ao trecho em que é dito que Bragi compôs versos sobre o tema: "The poet Bragi composed a poem on this story in the Lay of Ragnar Shaggy-Breeks" (YOUNG, 1954, p. 122). A tradução de Magalhães, por sua vez, não chega até esse trecho, terminando no evento em que o anão costura a boca de Loki com a correia Vartari (LIMA, 1993, p. 154). Além disso, a única incoerência grave é a de Gunnlöd, a gigante, ser apresentada como irmã de Suttung, quando se trata, no mito, de pai e filha.

As ilustrações presentes após a tradução são o mapa TO, o mapa da Escandinávia de acordo com os Vikings, o mapa da Germânia segundo Tacitus, o mapa das expedições Vikings e um mapa da Islândia. Todas as referências desses materiais estão listadas e explicadas ao fim da última. Não há índice; há um glossário, porém. Este traz nomes, substantivos e seus significados, como Freyia e seu significado "senhora" (Idem, 1993, p. 168). Alguns nomes são omitidos, como Frigg.

Linguisticamente, o trabalho tradutório é rico, constituindo-se numa tradução acadêmica - entenda-se esta por tradução feita por estudante da área ou acadêmico, com fundamento literário e/ou cuidado de pesquisa - que tem muito a acrescentar ao conhecimento do leitor. A leitura é fluida e instrutiva, e mínimas são as inadequações que podem prejudicar o entendimento e conhecimento da mitologia nórdica pelo leitor. Não há tendências deformacionais sistemáticas e o trabalho não é marcado por erros de tradução, originários de falhas no domínio de técnicas tradutórias, havendo apenas escassos erros na tradução - ortográficos, semânticos, morfossintáticos ou de conteúdo (AUBERT, 1994, p. 28).

Acerca da ortografia utilizada para os nomes próprios e para outros vocábulos em Nórdico Antigo, Marcelo Magalhães opta pela estrangeirização - termo advindo das teorias tradutórias de Lawrence Venuti (1995) -, a estratégia de utilizar informações da cultura-fonte na cultura-alvo, quebrando as convenções desta, a fim de preservar sentidos da primeira, nesse caso específico ao apresentar os nomes próprios e topônimos, entre outros vocábulos, de maneira próxima, quando não idêntica, ao nórdico antigo, permitindo ao leitor conhecer Odin, Thor e companhia através de uma grafia não aportuguesada Óðinn, Baldr, Dórr. Essa postura demonstrou fidelidade do tradutor ao seu projeto de 
interação dos lusófonos no que diz respeito às grafias de nomes próprios em Nórdico Antigo. Entre as adaptações fonéticas que faz, há a de substituir q por ö, como em Skjöld (LIMA, 1993, p. 40) e Valhöll.

Quanto à marcação de diálogos, esta é feita pelo uso de travessões e espaços no discurso direto, aproximando a forma da tradução à sua correspondente na cultura literária de língua portuguesa, o que poderia ser entendido como uma domesticação segundo a teoria bermaniana.

\section{Marcio Alessandro Moreira}

De 2008 a 2010, Marcio Alessandro Moreira, um interessado pela mitologia e cultura nórdica, traduziu três seções da Edda em prosa: Gylfaginning, Skáldskaparmál e Nafnapulur, disponibilizando-as em rede no blog Nibelung's Alliance, sendo este referente ao compartilhamento de materiais e conhecimento da mitologia nórdica, principalmente com fins religiosos. Não há menção das referências bibliográficas utilizadas para essa tradução, nem da língua do original utilizado. A tradução é eletrônica, não tendo sido impressa nem constituído livro, mas arquivos com o nome de diferentes seções da Edda: "Gylfaginning" (2008), "Nafnapulur" (2009 - 01-26) e "Skáldskaparmál" (2009), este último dividido em arquivos menores (01-04; 11; 12-23; 24-25; 26; 27-30, 40-43).

Em entrevista virtual por e-mail, concedida no segundo semestre de 2015, Moreira afirmou que esta tradução teria sido feita diretamente do islandês com traduções do inglês usadas como apoio, porém não foram citadas referências. Apesar de haver uma preocupação com a fidelidade tradutória, "Tentei manter-me fiel na tradução e em preservar os nomes originais" (MOREIRA, 2008, 2009, 2010), não são dadas referências ao leitor quanto ao original. Por este contato eletrônico com o tradutor foi possível conhecer a sua nova tradução, datada de 2013. Esta é formada por "Edda em prosa: Prólogo e Gylfaginning" (2008, 2013), "Skáldskaparmál” (2009, 2010, 2011, 2013) e "Nafnapulur" (2009, 2013 dividido conforme a versão anterior). Tendo conhecimento de que a segunda tradução teria sido recriada mais recentemente, podendo haver algumas alterações consideráveis em relação à primeira tradução, a análise do trabalho de Marcio Moreira partirá principalmente, mas não exclusivamente, dessa tradução mais recente, em que o tradutor atesta que sua tradução "não visa nenhum tipo de lucro, apenas divulgar a religião e mitologia nórdica", com a mais antiga (MOREIRA, 2013), e também da análise de trechos intercalados entre uma e outra tradução.

Antes do "Prólogo", que não consta da primeira tradução (2008), Moreira diz ser esta a parte inicial da Edda de Snorri, parte que explicaria "a origem da mitologia nórdica através do everismo da igreja [sic]". Assim como Marcelo Magalhães e o próximo tradutor a ter suas obras analisadas, Artur Avelar, Moreira relata o fato de alguns pesquisadores acreditarem ser esse trecho uma edição tardia à obra de Snorri, hipótese não descartável. 
O tradutor menciona o uso do Códex Regius GKS 230744to (Konungsbók), do Códex Wormianus (Ormsbók ou Wormsbók), do Códex Upsaliensis (Uppsalabók) e do Códex Traiectinus (Trektarbók) (MOREIRA, 2013).

Nesse Prólogo (2013) notam-se usos incoerentes da crase e inadequação de alguns tempos verbais que podem tornar a leitura menos fluida ou menos prazerosa a um leitor exigente.

Há resumos do Prólogo e de suas partes logo após a tradução. Nele tem-se informações acerca do significado de "spákona” e "spadómr", (Idem, P2013, p. 7), respectivamente, "profetisa" e "dom da profecia" (Idem, P2013, p. 13). Esse resumo se apresenta como adendo do tradutor válido a seu público na busca de explicação sobre vocábulos do nórdico antigo, seus significados e personagens de referência. Outra explicação que aparece entre os resumos traz uma anotação incoerente do tradutor, que afirma que "o autor do prólogo parece ter se confundido em alguns trechos”, pois, conforme o Professor John Lindow em aulas ministradas no primeiro semestre de 2015, na matéria Mitologia Viking, na UNM, sabe-se que havia mais de uma versão para os mitos, que foram transmitidos oralmente, dando assim origem a variantes que poderiam explicar possíveis diferenças míticas da Edda de Snorri em relação à Edda poética. Apesar destes detalhes, por vezes presentes em outras seções, e ainda conforme Aubert (1994, p. 82), nenhuma destas falhas podem ser consideradas "de tradução", ou seja, relacionadas à capacidade de traduzir e lidar com estratégias tradutórias, sendo, na verdade, falhas "na tradução", de conhecimento ou informação.

Cabe notar que a Edda também não data de 1220/2, conforme Moreira, mas de cerca de 1325. As perguntas e hipóteses levantadas pelo autor confirmam sua intenção de estabelecer um diálogo sobre a mitologia, mas também certa falta de embasamento teórico para tanto, exemplificada pelo questionamento em que pergunta "da onde o autor tirou” certos fatos, como a adoção do nome Njörd por Odin (MOREIRA, G2013, p. 9).

De Gylfaginning, comenta que "Snorri parece ter conhecido os poemas da Edda poética, porém ele se confunde nas sequências de algumas estrofes e outras aparecem levemente diferentes" (Idem, G2013, p. 14), trazendo, conforme dito anteriormente, comentários não relacionados às teorias e aos estudos que, a partir de evidências, afirmam que Snorri teria conhecimento desses poemas, mas, talvez por influência da tradição oral e variável, teria conhecido e utilizado determinadas versões dos mitos em detrimento de outras.

Embora ainda haja inadequações quanto à concordância, que trazem prejuízo à estilística tradutória, muito comum entre traduções sem apoio editorial, cabe enfatizar o fato de que poucos casos interferem no entendimento do texto. Um exemplo que não causa dificuldade interpretativa é "Essa parte do Ginnungagap que ia em direção ao norte ficou cheio de gelo [sic]" (Idem, G2013, p. 16), em que por concordância deveríamos adotar "cheia"; no uso do pronome "ti" por "te" em alguns contextos (Idem, PG2013, p. 28) e do verbo ir no passado no lugar do pretérito do futuro em "e os ventos iram 
então se tornando selvagens e raivosos" (MOREIRA, G2013, p. 20) [grifo nosso], que reiteram a noção de que as falhas apresentadas estariam "na", não sendo "da" tradução, do ato de traduzir.

Os diálogos são marcados por aspas duplas, não por travessão, como seria o costume no português do Brasil, de certa forma criando estrangeirização em todas as versões, pois passa a trazer ao leitor brasileiro a forma de marcação de diálogo mais comum à literatura em questão. $O$ tradutor também opta pela estrangeirização em outros casos, aparentemente na tentativa de aproximar o leitor da cultura apresentada, de colocá-lo em contato com a cultura nórdica e com um pouco de sua língua. Assim, os nomes são escritos de acordo com o alfabeto, a fonética e a grafia originais, como em pórr, e abundam os verbetes não domesticados, como "örlög dos homens" no sentido de "destino dos homens" - "destinies of men" (MOREIRA, G2013, p. 21; FAULKES, 1995, p. 16). Nisso nota-se a sua tentativa de trazer o leitor brasileiro ao estrangeiro, se familiarizando com fonética, ortografia e vocábulos estrangeiros. Sobre a utilização dos nomes das personagens de acordo com a fonética do islandês, adota tanto p quanto ð.

Apesar de o tradutor apresentar os significados dos verbetes e explicações referentes aos nomes citados apenas no final do arquivo, sem ordem numérica que norteie o leitor no início do arquivo e sem qualquer indicação quanto à existência deste índice ao fim do texto, os leitores poderão adquirir conhecimento através dessa estratégia tradutória, em uma tradução que assim se esquiva das deformações de expansão ou clarificação no texto, que se dariam por adicionar parênteses ou apostos no texto-alvo a fim de clarificar tais expressões.

No final de sua tradução são apresentadas as notas referentes a cada capítulo. $\mathrm{Na}$ nota referente ao capítulo 3, o tradutor diz ser a visão de Snorri sobre Hel influenciada pelo cristianismo (MOREIRA, G2013), porém isso não é confirmado pela obra Norse Mythology: a Guide to Gods, Heroes, Rituals and Beliefs (LINDOW, 2001, p. 172-173). Já o Dicionário de Mitologia Nórdica, de organização de Johnni Langer (2015, p. 242-243), afirma a existência do mito antes do cristianismo, mas também menciona a visão cristianizada de Snorri, próxima do Inferno em termos estéticos, porém não funcionais, uma vez que não se trata de um lugar de punição, mas de descanso. As notas das aulas ministradas por John Lindow compartilham da ideia de Hel ser um lugar de descanso aos mortos, e não de punição, tendo sentido de "túmulo", que com o tempo foi sendo personificado, dando origem a "Hel", a filha de Loki. A criação não teria influência cristã, e, portanto, não poderia tratar-se de um lugar de descanso para todos nem de punição, uma vez que os mortos eram enviados a Hel de acordo com o tipo de morte que os acometera.

Moreira interpreta a Prosa éddica literalmente quando diz, na nota 9 do capítulo 9 , que ou "ela [Frigg] tinha outros filhos que não são recordados ou ela era mãe no sentido de ser carinhosa" (G2013, p. 56), posto que se pode entender que por sua relação com Odin ela passa a ser mãe de todos - um caso de extensão. 
A nota do capítulo 19 indaga sobre as origens de Sumarr e Vetr, porém eles são personificação do Verão e do Inverno na Edda, representando necessariamente uma raça - Moreira acredita serem eles, respectivamente, um dos Æsir e um dos gigantes. Essa interpretação vem do significado de ambos, "Sumarr" - o ameno sul, "Vetr" - o de coração frio. Sabe-se que os gigantes são representados comumente em relação às montanhas e ao gelo, ao que essa interpretação poderia ser atribuída.

É um equívoco Moreira afirmar que Saxo Grammaticus tenha se confundido quanto ao mito de Loki no Ragnarök, no Capítulo 50, pois, como dito anteriormente, havia mais de uma versão aos mitos.

$\mathrm{Na}$ nota do Capítulo 51 o tradutor contesta o mito de várias formas, entre elas duvidando do poder de Bifröst diante de seu fim em Ragnarök, porém, como dito nas Eddas e exposto por teóricos como John Lindow, nada poderia poupar os deuses de seus destinos. Por extensão, Fenrir não tem como ser libertado pelo terremoto de Loki, Bifröst pode ser atravessada pelos gigantes na data do Ragnarök e é apenas neste evento que Ásgard pode ser invadida. Ao contrário do que afirma, não se trataria de simulacros para desacreditar o paganismo, mas de símbolos da fatalidade do destino na mitologia - uma ideia compartilhada pelas personagens na série Vikings, em que com frequência personagens falam sobre destino. $\mathrm{O}$ mesmo pode ser dito da nota 54: os deuses nórdicos não usariam nomes do passado para enganar os homens, mas porque os teriam recebido em função das viagens a diferentes reinos.

As referências dos capítulos 6, 9, 10, 11, 15, 16, 23, 32, 35, 36, 43, 44, 46, 48, 50 e 51 não foram avaliadas pela presente autora por falta de materiais de referência. As demais notas não trazem prejuízo ao entendimento ou informações que possam levar a equivocada interpretação. A presente autora também se absteve da análise de referências topográficas, dada a sua relação com os textos literários éddicos mais do que entendimento geográfico.

A seguir vem o índice alfabético de personagens e depois as citações poéticas da Edda em prosa por capítulo. O índice de personagens traz Fjorgvin/Fjorgun (FAULKES, 2012, p. 312) como Fjörgvynn (MOREIRA, G2013, p. 69). Fulla é dita "criada de Frigg” (Idem, G2013, p. 69); Hoddmímir, que Faulkes diz ser o nome de um gigante ou um kenning para homem bondoso, é traduzido como "um bosque que protegerá os humanos do Ragnarökr" (MOREIRA, G2013, p. 71). Nota-se que Moreira, como parte da literatura em mitologia nórdica, considera Mímir um gigante (G2013, p. 72).

Na segunda versão do Skáldskaparmál (2009, 2010, 2011, 2013), Marcio Moreira apresenta essa seção como a "Linguagem da Poesia" e terceira parte da Edda em prosa. Sua compilação omite certos trechos, suprimidos por conta da intenção de manter apenas os trechos mitológicos, objetivo próximo ao de Lima, ainda que tenham alcançado trechos diferentes.

A tradução da listagem dos nomes se atém à vigésima sexta parte, que alcança Nipt e Dísir, não se estendendo até outras listas de nomes uma vez que tem por objetivo listar fatos apenas sobre os Poderes. O tradutor introduz sua nota dizendo ser esta 
"uma listagem poética de várias categorias sobre os Deuses, os Jötnar ('Gigantes”), as Trollkonur ('Fêmeas Trolls') e outros seres" (MOREIRA, N2013, p. 1). De fato, eles serão listados, mas além deles, outros também serão - haja vista que a proposta de Snorri era a de listar os nomes referenciais para o uso poético dos escaldos, havendo uma listagem de nomes para cada referente.

Em “desejo nomear” (MOREIRA, N2013, p. 4) há um erro de pessoa, posto que se trataria, na verdade, do plural "We wish to name" (FAULKES, 1995, p. 156). Na listagem dos Æsir, após “Heimdall e Sæming” (Idem, 1995, p. 156), Marcio Moreira adiciona Höðr e Bragi (N2013, p. 4). Vingrip (FAULKES, 1995, p. 157) é apresentado como Víogrípr (MOREIRA, N2013, p. 4) e Grimling (FAULKES, 1995, p. 157) como Gillingr (MOREIRA, N2013, p. 5).

Quanto a excertos marcantes da tradução, seja por conta das estratégias utilizadas ou de trechos relacionados à recepção por parte do leitor, temos as seguintes considerações a fazer.

Da quarta página do "Prólogo", ao traduzir "the same earth, sun" (FAULKES, 1995, p. 2), Moreira interpreta "sun”, desta seção, como a divindade de Gylfaginning, apesar de considerá-la uma adição posterior à Edda. Dessa forma, Moreira traduz o trecho anterior como "desde que existia a terra e Sól”. Isso ocorre novamente no trecho em que cita o brilho do sol, "the shining of the sun" (Idem, 1995, p. 2), como "o brilho da Sól", interpretando o fato como a apresentação da divindade, não apenas do astro solar, de certa deixando o original "revelar-se" na tradução, conforme as ideias apresentadas por Berman (2000).

A segunda parte do "Prólogo", "Como o mundo se dividiu em três partes", é parte constante apenas em sua tradução, ausente na de Faulkes, Magalhães e Avelar (MOREIRA, P2013, p. 5).

Nessa tradução, a mais recente, optou-se por traduzir a "ark" de Bergelmir (FAULKES, 1995, p. 11) como moinho, não arca, promovendo, de acordo com a teoria bermaniana, que preza pela estrangeirização, o empobrecimento de cadeias subjacentes de significação, como a da relação dos funerais vikings a arcas e barcos, perdida nessa estratégia tradutória de Moreira, enquanto na primeira versão (G2008) essa concepção é trazida pelo referente "barco". Ainda assim é possível observar que há outro mito em que o referente é o moinho do mundo, Grótti, em que Ymir e Bergelmir são colocados e onde seus cadáveres são triturados, conforme comentário do editor, ainda que não seja na Edda em prosa, ao que uma outra abordagem teórica poderia entender como enriquecimento de cadeias subjacentes de significação. Assim, no poema que acompanha esse evento, Marcio Moreira (G2013, p. 18) traduz "quando o sábio Jötunn / foi colocado em um moinho" para "when that wise giant was laid on a box" (FAULKES, 1995, p. 11), trecho que se refere metaforicamente à morte de Ymir, que foi "deitado numa caixa", não à escapada de Bergelmir.

Moreira (G2013, p. 19) traduz "eyelashes” de Ymir (FAULKES, 1995, p. 12-13) como "sobrancelhas do Jötunn Ymir". Porém, "Baldr’s eyelash” (Idem, 1995, p. 23), "cílio 
de Baldr", em outro contexto é traduzido como "pálpebra": "uma flor tão branca que foi assim chamada depois da pálpebra de Baldr" (MOREIRA, G2013, p. 28). Ainda traduz "isso é feito sem ilusão" (Idem, G2013, p. 33) num contexto em que seria mais adequado o uso da expressão "de boa fé", o que pode levar o leitor a uma interpretação do contexto como mágico, referindo-se à magia ou à ilusão, ao invés de propor o sentido de honestidade, o que faz com que se percam cadeias subjacentes de significação relacionadas a tratos e acordos.

Ao falar dos Æsir, ele diz serem tod(as) as divindades: “e eles são todas as divindades” (MOREIRA, G2013, p. 19), mas essa estratégia pode levar o leitor a erro ao afirmar serem os Æsir tod(as) as divindades, como se fossem a única totalidade divina, quando ainda há os Vanir. Isto é, traria menos ambiguidade interpretativa afirmar "eles todos são divindades", um caso de erro na tradução.

Ao tratar dos eventos da construção da fortaleza de Midgard é dito que os Æisir "bateram em Loki" (Idem, G2013, p. 38), quando na verdade eles ameaçaram bater em Loki - "they offered to attack" (FAULKES, 1995, p. 36) -, o que gera a ideia de uma simples possibilidade, que na primeira versão tradutória de Moreira também não é considerada, tendo-se "Loki foi então agredido" (G2008, p. 26).

No evento de Skrýmir é posto que este "os encontrou [Thor, Loki, Thialfi e Roskva] debaixo de um grande carvalho" (MOREIRA, G2013, p. 41), porém estes encontram um grande carvalho como abrigo, não como um ponto de encontro. Quanto a esse evento, nas duas versões nota-se uma sintaxe estranha ao português, motivada pela tradução literal, no seguinte trecho: "Então Skrýmir pegou e soltou sua bolsa de provisões" (segunda versão) e "Skrýmir pegou e soltou sua bolsa de provisões" (primeira versão), que teria uma fluência mais natural se trouxesse "Skrýmir então pegou sua bolsa de previsões e soltou-a”. A primeira versão parece menos fluida, também, no trecho em que fala do insucesso de Thor quanto a soltar o nó da bolsa de provisões de Skrýmir, em que tem-se "Mas, porém, incrível que pareça em dizer, ele não teve sucesso em soltar nenhum nó, nem para soltar ainda um pouco do primeiro" (MOREIRA, G2008, p. 29), em oposição à segunda versão, em que temos "mas por incrível que pareça em dizer, ele não teve sucesso em desamarrar nenhum nó e nem mover a extremidade da tira de couro, de modo a torná-lo menos apertado do que já era” (Idem, G2013, p. 41), posto que explica-se que nem mesmo a extremidade do nó fora mexida em oposição à primeira versão, que sugere que o saco teria mais de um nó.

No trecho que trata do evento em que Thor arremessa Mjolnir contra Skrýmir, a primeira versão mostra-se incompleta em oposição à segunda e à tradução de Faulkes: "e bateu no lado de uma de suas têmporas" (Idem, G2008, p. 29); "bateu no lado de uma de suas têmporas, que estava voltada para cima. Então o martelo afundou até o cabo" (Idem, G2013, p. 41); "and he [Thor] got up and ran at him, swung the hammer with all his might and struck at the temple that was facing upwards. Then the hammer sank in up to the handle" (FAULKES, 1995, p. 40). Nota-se que não só pela supressão da segunda 
frase na primeira versão a segunda se assemelha mais à tradução de Faulkes, mas também pelas descrições mais detalhadas do evento e de suas consequências, o que contribui à manutenção do tom e do ritmo da Prosa de Snorri.

Há outra diferença entre as versões no trecho sobre a despedida de Thor e Skrýmir, sendo que a primeira versão afirma que os Æsir não desejou boa sorte ao segundo, enquanto a segunda relata a falta de fé num possível reencontro feliz: "depois daquele momento os Æsir não o desejou boa sorte" (MOREIRA, G2008, p. 30); "não há relato, que os Æsir expressaram esperança para um feliz encontro" (Idem, G2013, p. 42). Nota-se também a incoerência de concordância na primeira versão, em "os Æ̇sir não desejou", e a incoerência em separar "não há relato" de seu complemento "que os Æsir" na segunda versão. Vale notar, porém, que a segunda se aproxima da versão de Faulkes, em que é dito que não foi expressada esperança de uma feliz reunião, e ambas traduzem o evento não de forma literal, palavra por palavra, mas sentido por sentido, através de uma metáfrase, conforme o termo empregado por John Dryden: "there is no report that the Æsir expressed hope for a happy reunion" (DRYDEN apud BASSNET'T, 1988; FAULKES, 1995, p. 40).

A palavra "contesto" (MOREIRA, G2008, p. 31; idem, 2013, p. 43) mostra-se como tradução fonética do inglês, "contest", porém sendo ineficaz no ponto de não ser a usual, talvez desconhecida ao público. No contexto de uso no português, poderia optar-se por torneio ou competição. Embora essa criação fosse aceita em alguns contextos, na tradução de uma obra com objetivo metafrástico e ao início dos estudos da mitologia, como esta, não se aplicaria, de todo modo, uma estrangeirização terceirizada.

Nas traduções de Marcio Moreira o povo, "people”, (FAULKES, 1995, p. 44), de Utgarð-Loki, é traduzido como "capangas" (MOREIRA, G2008, p. 31) e "servos" (Idem, G2013, p. 44). Esse uso de "capangas" traz ao imaginário da mitologia nórdica uma domesticação própria do imaginário brasileiro, advindo de contextos como o cangaço e o coronelismo, o que de certa forma passa a dialogar com as tendências deformacionais por se utilizar de um referente regional que promove a desintegração de cadeias de sentido subjacentes advindas do original.

$\mathrm{Na}$ ocorrência do aparecimento do nome completo de Loki, Moreira opta pela estrangeirização, apresentando-o na forma islandesa "Loki Laufeyjarson" em ambas traduções, sendo que o segundo nome é o sobrenome que indica a linha patriarcal/matriarcal da pessoa. Porém, no evento da morte de Baldr, a versão de 2008 traz "Loki Laufeyjarson", enquanto a versão de 2013 apresenta ao leitor "Loki, o filho de Laufey". Nessa mudança nota-se a intenção de domesticar o que outrora deixara na forma estrangeirizada, mostrando haver uma maior preocupação com o entendimento das linhas familiares e nomes, ao mesmo tempo em que se vale da expansão de significado.

A segunda versão parece mais fluida linguisticamente, mais natural e coerente, sendo que no evento sobre o lobo e as correntes, mostra que "eles levaram a fita que estava fixada nessa corrente" - havia essa fita na corrente, não o inverso, como dito na 
primeira versão: "eles pegaram a corrente que estava fixada nessa fita", trecho solucionado pelo tradutor com recurso à racionalização, ou seja, clarificação do texto original com adição na tradução.

$\mathrm{Na}$ primeira tradução, o trecho "tentador da mente (Dórr)" pode levar o leitor a erro, fazendo com que creia que Thor seria o tentador da mente, quando na verdade Loki tenta a Thor, e não o contrário, o que passa uma ideia errônea sobre as personagens mitológicas em questão.

No trecho do evento da luta de Thor contra o gigante, Moreira traduz o nome do martelo usado por este como Mjöllnir, "com o fácil esmagador (Mjöllnir)" (G2008, p. 26), porém o artefato usado pertence a Grid e não tem este nome, o que caracteriza uma possível falha problemática à apresentação da mitologia a novos leitores e gera uma disposição errônea de cadeias de significados, pois aqui trata-se do bastão de Gríðr.

O trecho da segunda versão, "Aqui é relatado isso, quando Skaði deixou Njördr, como foi escrito antes", é suprimido na versão mais antiga. Alguns dos parênteses explicatórios também não constam.

Quanto à primeira tradução, o "Gylfaginning” (2008) não é acompanhado do "Prólogo", mas parte da ilusão de Gylfi e termina no evento de Loki e Syf, cabelos de ouro. A seguir vêm as notas. Os resumos dos capítulos trazem reflexões, mais do que discussões acadêmicas, por exemplo ao basear-se na idade dos manuscritos para atribuir veracidade aos relatos da Edda. Sua Skáldskaparmál é formada pelos trechos 01-04, 11, 12-23, 24-25, 26, 27-30 e 40-43. Seguem as referências de citações poéticas do Skáldskaparmál por ordem de aparecimento, sendo que, na seção 25, Moreira diz não haver as passagens de Haustlong (MOREIRA, S2008, p. 3) no Uppsala Edda, mas trata-se de informação errônea quando se consulta a edição da Uppsala editada por Pálsson, tanto que essa omissão se verifica apenas na primeira tradução, não na segunda. Essa supressão também se repete na seção 30. Erros gramaticais ou linguísticos encontrados nas outras seções também aparecem nessa versão, como em "soprara" e "golpeara" sem acento (Idem, 2009, 2010, 2011, 2013, p. 5).

Essa versão apresenta traduções dos termos estrangeiros utilizados, como Álfr, Álfar, Áss, Æsir, Ásynja, Ásynjur, Bergrisi, Bergrisar, Dvergr, Dvergar, Gýgr, Gýgjur, Hrímpursar, Jötunn, Jötnar, Norn, Nornir, Regin, Purs e Pursar. Não há resumo de capítulos nem de versos; não há índice poético, mas ambas traduções contribuem para um conhecimento inicial da matéria, que pode ser incompleto ou incorreto em alguns pontos, mas de forma geral tem mais a contribuir ao leitor do que o inverso.

Algumas particularidades de ambas traduções ainda são notadas, sendo apresentadas na tabela a seguir à luz da tradução de Faulkes e acompanhadas por comentários relativos à análise da tradução. 


\begin{tabular}{|c|c|c|}
\hline Tradução de Moreira & Tradução de Faulkes & Comentários \\
\hline $\begin{array}{l}\text { "Na velhice, Noé dividiu o mun- } \\
\text { do (...) Senaar" (P2013, p. 4) }\end{array}$ & $\begin{array}{l}\text { "which was called Troy" } \\
(1995, \text { p. 3) }\end{array}$ & $\begin{array}{l}\text { Troia é então traduzido por "Se- } \\
\text { naar". }\end{array}$ \\
\hline $\begin{array}{l}\text { "que ele dificilmente pode ver } \\
\text { até o topo" (P2013, p. 14) }\end{array}$ & & $\begin{array}{l}\text { No excerto, o tradutor opta pelo } \\
\text { uso do verbo poder no presen- } \\
\text { te, entretanto, no contexto, seria } \\
\text { necessário o uso do mesmo no } \\
\text { passado. }\end{array}$ \\
\hline $\begin{array}{l}\text { "E de um passo adiante" } \\
(\mathrm{G} 2013 \text {, p. 15) }\end{array}$ & & $\begin{array}{l}\text { No trecho há falta de acento, "E } \\
\text { dê um passo adiante", por tratar- } \\
\text {-se de um comando de Hárr a } \\
\text { Gylfi. }\end{array}$ \\
\hline $\begin{array}{l}\text { "Höll” (G2013) } \\
\text { "Veg" (G2013) }\end{array}$ & $\begin{array}{l}\text { "Boll" (1995, p. 34) } \\
\text { "Holl" (2012) }\end{array}$ & \\
\hline "Vegsvinn" (G2013, p. 37) & $\begin{array}{l}\text { "Svinn" (1995, p. 34) } \\
\text { "Veglun" (2012) }\end{array}$ & \\
\hline "prostituição" (G2013) & “depravity" (1995, p. 53) & \\
\hline $\begin{array}{l}\text { "vem à / segunda aflição" } \\
(\text { G2013) }\end{array}$ & & $\begin{array}{l}\text { Constitui incoerência, posto que } \\
\text { aqui trata-se de uma inversão } \\
\text { sintática, em que a ação é da "se- } \\
\text { gunda aflição", e não de outrem } \\
\text { a dirigir-se a ela, devendo-se ter } \\
\text { "vem a / segunda aflição". }\end{array}$ \\
\hline $\begin{array}{l}\text { "do céu muda / as estrelas bri- } \\
\text { lhantes" (G2013, p. 52), }\end{array}$ & “vanish" (1995, p. 55) & \\
\hline $\begin{array}{l}\text { "se encontraram" (G2013, p. } \\
52)\end{array}$ & "shall wade" (1995, p. 56) & $\begin{array}{l}\text { Falha ortográfica, sendo o corre- } \\
\text { to: encontrarão. }\end{array}$ \\
\hline “runas” (G2013) & $\begin{array}{l}\text { "discuss their mysteries" } \\
(1995, \text { p. 56) }\end{array}$ & $\begin{array}{l}\text { No caso, nota-se que Moreira } \\
\text { interpretou tais mistérios como } \\
\text { referentes às runas, mas estes } \\
\text { também poderiam ser entendidos } \\
\text { de forma mais abrangente como } \\
\text { o poder dos Æsir na totalidade. }\end{array}$ \\
\hline $\begin{array}{l}\text { "Gjallarhorn" (G2013) } \\
\text { "Gjall” (idem) }\end{array}$ & & $\begin{array}{l}\text { Nota-se mudança dos termos en- } \\
\text { tre as versões. }\end{array}$ \\
\hline "Gefjun” (G2008) & "Gefjan" (1995) & \\
\hline $\begin{array}{l}\text { "todos os tolos" (G2013, p. 24) } \\
\text { "tolos macacos" (G2008, p. 12) }\end{array}$ & "any old fool" (1995, p. 19) & \\
\hline $\begin{array}{l}\text { "Býleistr" (G2013) } \\
\text { "Býleist" (G2008) }\end{array}$ & “Býleistr" (2012) & \\
\hline
\end{tabular}




\begin{tabular}{|c|c|c|}
\hline $\begin{array}{l}\text { "Narfi e Nari” (G2013) } \\
\text { "Narvi, Nari ou Narfi" (G2008) }\end{array}$ & "Nari”, "Narfi" (1995) & \\
\hline $\begin{array}{l}\text { "cidade" (G2013) } \\
\text { "instalação" (G2008) }\end{array}$ & & $\begin{array}{l}\text { A primeira versão trata do reino } \\
\text { de Odin como cidade, a segunda } \\
\text { como instalação. }\end{array}$ \\
\hline $\begin{array}{l}\text { "'jjálfr" (G2013, p. 42; G2008, } \\
\text { p. 30) }\end{array}$ & "Djálfi" (2012) & \\
\hline $\begin{array}{l}\text { "Himinhrjóðr" (G2013, p. 45) } \\
\text { "Himinhrjótr" (G2008, p. 34) }\end{array}$ & “Himinhrjótr" (2012) & \\
\hline $\begin{array}{l}\text { "fundo do mar circulando o oce- } \\
\text { ano" (G2013, p. 46) } \\
\text { "circulando a terra" (G2008, p. } \\
\text { 34) }\end{array}$ & $\begin{array}{l}\text { "lies in the encircling sea" } \\
(1995, \text { p. } 47)\end{array}$ & $\begin{array}{l}\text { Sobre Jormungandr, a serpente } \\
\text { de Midgard. }\end{array}$ \\
\hline $\begin{array}{l}\text { "Como é dito" (G2013) } \\
\text { "Se todas as coisas" (G2008) }\end{array}$ & $\begin{array}{l}\text { "And if all things in the } \\
\text { world" (1995, p. } 50)\end{array}$ & $\begin{array}{l}\text { O trecho do discurso de Hel so- } \\
\text { bre a morte de Baldr assemelha- } \\
\text {-se ao da tradução de Faulkes na } \\
\text { primeira versão em oposição à } \\
\text { segunda, que une ao discurso de } \\
\text { Hel a introdução ao seu discurso. }\end{array}$ \\
\hline $\begin{array}{l}\text { "dai a humanidade nascerá" } \\
\text { (G2013, p. 54) } \\
\text { "Assim deve a humanidade ser } \\
\text { nutrida" (G2008, p. 42) }\end{array}$ & $\begin{array}{l}\text { "and from them shall grow } \\
\text { mankind" (1995, p. 57) }\end{array}$ & $\begin{array}{l}\text { Nesse excerto a tradução mais } \\
\text { antiga de Moreira parece mais } \\
\text { poética em oposição à recente, } \\
\text { mais literal. / Ao mesmo tempo } \\
\text { tem-se o recorrente erro de acen- } \\
\text { tuação, com a falta de grafo em } \\
\text { "dai". }\end{array}$ \\
\hline $\begin{array}{l}\text { "O segundo tem que chamar } \\
\text { por um pronome" (S2009, 2010, } \\
2011,2013, \text { p. 4) }\end{array}$ & & $\begin{array}{l}\text { Há inconsistência na explicação } \\
\text { dos kenningar na não determina- } \\
\text { ção do que seria seu "primeiro } \\
\text { elemento", um substantivo, ge- } \\
\text { ralmente, mas fala-se apenas do } \\
\text { "segundo", descrito por Moreira } \\
\text { como um "pronome", o que gera } \\
\text { um empobrecimento qualita- } \\
\text { tivo. }\end{array}$ \\
\hline $\begin{array}{l}\text { "Farmatýr" (S2009, 2010, 2011, } \\
\text { 2013, p. 5) }\end{array}$ & “Cargo-Tyr" (1995, p. 67) & \\
\hline $\begin{array}{l}\text { "Deuses do Fiorde" }(\text { S2009, } \\
\text { 2010, 2011, 2013, p. 7) }\end{array}$ & $\begin{array}{l}\text { "deities' fiord" (1995, p. } \\
68)\end{array}$ & $\begin{array}{l}\text { Nesse contexto seria mais coe- } \\
\text { rente que tivéssemos "Fiorde dos } \\
\text { Deuses". }\end{array}$ \\
\hline $\begin{array}{l}\text { "Que sonho é esse, Odin," } \\
(\mathrm{S} 2009,2010,2011,2013, \text { p. 9) }\end{array}$ & & $\begin{array}{l}\text { Falta ponto de interrogação nesse } \\
\text { trecho, que traria "Que sonho é } \\
\text { esse, Odin." }\end{array}$ \\
\hline
\end{tabular}




\begin{tabular}{|c|c|c|}
\hline $\begin{array}{l}\text { "Ulfr Uggarson" (S2009, 2010, } \\
\text { 2011, 2013) }\end{array}$ & "Eilífr" (1995, p. 53) & \\
\hline $\begin{array}{l}\text { “Então Pórr disse isso:” (S2009, } \\
\text { 2010, 2011, 2013, p. 21; S2010- } \\
\text { 26) }\end{array}$ & & Não consta em Faulkes. \\
\hline $\begin{array}{l}\text { "Skotum (Escoceses)" } \\
(\text { S2009, 2010, 2011, 2013, p. 22) }\end{array}$ & $\begin{array}{l}\text { "White Sea Scots [giants]" } \\
(1995, \text { p. } 83)\end{array}$ & \\
\hline $\begin{array}{l}\text { "Böðvarr balti" (S2009, 2010, } \\
\text { 2011, 2013, p. 28) }\end{array}$ & "Kolli" (1995, p. 81) & \\
\hline $\begin{array}{l}\text { "sobre" (S2009, 2010, 2011, } \\
\text { 2013, p. 28) }\end{array}$ & & $\begin{array}{l}\text { Seguindo a tradução de Faulkes } \\
(1995, \text { p. 89), seria, na verdade, } \\
\text { sob. }\end{array}$ \\
\hline $\begin{array}{l}\text { "Hamlet" (S2009, 2010, 2011, } \\
\text { 2013, p. 32) }\end{array}$ & "Amloði" (1995, p. 134) & \\
\hline
\end{tabular}

Nota-se nessa coletânea a evolução da interpretação de um leitor no seu ato tradutório, que a cada seção buscou se alinhar ao seu projeto de divulgação da cultura nórdica. Abundam casos de deformação de cunho de clarificação, expansão, há casos de exotização e popularização, ainda, principalmente com uso de referentes próprios do imaginário brasileiro, e casos de destruição de cadeias subjacentes de significação. Apesar disso, dos exemplos coletados de trechos poéticos, nota-se criatividade e agência tradutória, que provêm o leitor com informação e uma introdução à mitologia nórdica. Ainda pode haver outros trechos de adaptação, incorreções ou inconsistências, mas cabe enfatizar a importância dessas obras na inserção de leitores ao diálogo sobre o tema da mitologia nórdica e de sua literatura.

\section{Artur Avelar}

Artur Avelar, estudioso da área de Engenharia, interessado pela cultura nórdica e sua divulgação no Brasil, foi responsável pela tradução da Edda em prosa em formato e-book e os publicou na Amazon com sua Editora Barbudania. Em 2015, também produziu uma versão impressa de sua tradução, idêntica à do e-book. A versão traz Gylfaginning: a ilusão de Gylfi (2013) e Gylfaginning e Skáldskaparmál (2014). Em sua introdução de Gylfaginning e Skáldskaparmál, Avelar discorre sobre a Edda em prosa de Snorri, chegando a dizer que este "foi famoso por defender a teoria de que os deuses mitológicos surgiram a partir de figuras históricas que lutaram em combate e reis que, após mortos, eram invocados em guerras constantemente, sendo venerados até serem lembrados somente como deuses", alinhando seus conhecimentos evemeristas de Snorri aos de Marcio Moreira. Afirma ainda 
que Snorri chegou "a ser acusado de até inventar histórias em momentos em que ele não cita excertos de poemas de onde retirou as lendas", o que é feito por Moreira em sua introdução às seções da Edda. Essa possibilidade de Snorri ter adicionado versões de lendas às da Edda citada por ambos, como dito anteriormente, foi refutada por dados apresentados em aulas ministradas na UNM, na disciplina Viking Mythology, durante a primavera de 2015. John Lindow comenta que na época, como a Edda era de tradição oral e como diferentes versões de seus mitos teriam coexistido, Snorri teria trazido apenas algumas dessas possibilidades, ao passo que outras não foram contempladas pelos manuscritos da Edda poética a que temos acesso atualmente. Mas, além disso, o tradutor faz referência, nas primeiras páginas, às obras de sua referência, The Younger Edda de Rasmus Anderson (1897) e The Prose Edda de Arthur Gilchrist Brodeur (1916). Daí temos que sua tradução acontece do inglês ao português, não sendo uma tradução direta a partir do nórdico antigo. Sua tradução traz o "Prólogo", "Gylfaginning", "Skáldskaparmál” e "Nafnapulur".

Assim como nas traduções de Moreira, os diálogos das traduções de Avelar são apresentados com aspas, como no inglês, e não com travessão, modo mais comum ao português, adotando uma abordagem estrangeirizante.

Sua tradução não se utiliza de notas explicativas, sendo o vocabulário “Öku-Thor” apresentado apenas como "e uma carruagem na qual ele dirige, e os bodes puxam-na, por isso ele é chamado de Öku-Thor" para "[driving-Thor]" (FAULKES, 1995, p. 22), mantendo ambígua ao leitor a origem do nome, que pode ser lido tanto em referência à carruagem ou aos bodes - contexto em que seria importante uma nota explicativa ou outra estratégia que não a expansão, mas que ainda assim diminuísse a possibilidade de dupla interpretação.

Embora haja menos ocorrências, se comparada à obra de Moreira, as traduções de Avelar também trazem erros ortográficos, como a que é encontrada em "No lugar chamado Bosque de Hoddmímir se esconderam durante o Fogo de Surtr dois da raça humana", pois utilizou-se "am” em vez de "ão", do futuro do presente, "esconderão", tratando-se de trecho de vidência; também na apresentação de "então os Æsir acenderem o fogo", em que se deveria ter "acenderam". Seria mais adequado ter, também, "a fim de que as pessoas acreditassem que eles fossem" para a tradução "a fim de que as pessoas deviam acreditar que eles fossem", escolhida por Avelar. Porém, ainda que haja mais de uma incoerência na tradução, elas não mostram falta de competência, sendo alguns casos de necessidade de revisão textual apenas, constituindo falhas na tradução. Também são encontradas falhas de revisão como a gralha "seu fundoe, mas".

Assim como na tradução de Moreira, "eyelash of Baldr” é traduzido nessa edição por "sobrancelha".

Para o trecho "From Gna's name a thing is said to tower (gnaefa) when it goes high up" (Idem, 1995, p. 31), Artur Avelar opta pela tradução "Do nome da Gná aquele que voa alto é chamado de gnæfa”, o que se relaciona à deusa apresentada que voa, Gná. Marcelo Magalhães, porém, adota tradução mais poética, optando por dizer que "Do nome 
de Gnár, aquilo que alto ressoa é chamado gnæfar” (LIMA, 1993, p. 90), notando-se que cada qual usa de liberdade poética na tradução parafrástica.

A tradução necessita de negativa em "Mas quando Loki viu isso, lhe agradou que Baldr não levava nenhum dano”, pois na verdade não agradou a Loki ver Baldr ileso, constituindo essa "afirmativa" falta que pode levar o leitor a interpretações erradas do evento, em que Loki trama contra o bem-estar de Baldr por não suportar vê-lo ileso, inibindo camadas superficiais de significação.

Ao contrário da tradução de Moreira, Skáldskaparmál na tradução de Avelar se mostra completa, não se atendo apenas a alguns eventos, mas passando por todos até alcançar o Nafnapulur.

Em "Que sonho é esse? disse Odin” há incorreção na interpretação de ter-se Odin como interlocutor. Na verdade, segundo Faulkes (1995, p. 69), é perguntado a Odin "What sort of dream is that, Odin?", "Que tipo de sonho é esse, Odin?", o que constitui diferença da tradução de Moreira, que deixa de apresentar o ponto de interrogação necessário ao contexto.

Há algumas omissões na tradução de Avelar, como o trecho "Hyrrokkin died previously" e o trecho "god of chariots" sobre Njord (FAULKES, 1995, p. 74; 75).

Muitos trechos da tradução trazem caracterização poética da linguagem usada na $E d d a$, alinhando-se com seu original, porém no trecho "eu teria matado esse gigante com meu punho", "I would have knocked this giant into Hel with my fist" (Idem, 1995, p. 79), a menção da figura "knocked this giant into Hel", "levado esse gigante a Hel" poderia ser de maior fidelidade à poética da obra mitológica, por estar mais alinhado à intenção poética do tradutor com sua prática na apresentação de figuras mitológicas e mitos, adequando-se assim às cadeias subjacentes de sentido da obra.

Depois do trecho de Faulkes "Under the seat it had been Geirrod's daughters Gialp and Greip and he had broken both their backs" (Idem, 1995, p. 82), Avelar adiciona os seguintes versos "Uma vez empreguei / Meu poder de deus / No reino dos gigantes. / Quando Giálp e Greip, Filhas de Geirrödr, / Tentaram me levantar aos Céus”, mas a partir daí o texto da tradução continua como a de Faulkes.

"Quando ele, que sempre balança o Cinturão de Força" é a tradução de Avelar para "when Idi's yard-visitor [Thor], mightier than White Sea Scots [giants]" (FAULKES, 1985, p. 83), na qual notamos a opção de passar de um referencial metafórico ao pragmático, de "Idi's yard visitor" para "Thor", deixando o trecho mais direto e claro para um leitor iniciante no estudo da mitologia nórdica, mas ainda assim constituindo alteração das expressões do texto. Porém, na tradução, nota-se o entendimento de Thor como aquele "que sempre balança o Cinturão da Força". Vale notar que ele o faz, realmente, porém não é a tradução esperada para o trecho que temos da tradução inglesa, que expõe Thor como "mais poderoso que os gigantes do Mar branco", "mightier than White Sea Scots”. 
Nota-se interpretação errônea do texto éddico na tradução "Assim que saiu das mãos / Do pai de Greip; / Seu peito com ódio inchou / Contra o pai de Thrúdr", uma vez que não é dito que o ódio vem de Geirrodr, o pai de Greip, mas sim que a barra de ferro voou das mãos do primeiro contra o pai de Thrud: "when the sparkling cinder flew furiously from the grip's breast [palm] of the passionate desirer [Geirrod] of Hrimnpir's lady towards the one who longs for for Thrud in his heart [Thor]" (Idem, 1995, p. 85). No poema é dito que a barra de ferro atinge o cinto de Geirrod, mas Artur Avelar traduz por "cabeça", "Quando ele atingiu, / Com sua larga cabeça, / Contra a velha viga da caverna”. Por ser dito que a cabeça de Geirrod atingiu uma viga após ele ser atingido pela barra de ferro, o tradutor parece ter suposto que a barra de ferro tenha atingido a cabeça diretamente, não seu cinto ou cintura (figurativamente) em: “Thrasir's hall [giant's cave] shook when Heidrek's [giant's] broad head was brought under the old wall-leg [pillar] of the platform-bear [house]. Ull's splendid stepfather struck the hurting-pin [piece of iron] hard down in the middle of the belt of the fishing-line-way-[sea-]tooth [rock] villain [giant].” (FAULKES, 1995, p. 85). Tem-se erro na tradução na interpretação particular e empobrecimento qualitativo.

Quando se lê que os personagens foram "Arrastados pela fúria monstruosa / Do terrível opressor" temos outro momento de tradução metafórica, muito mais que literal, para o trecho "The earth-drift-[mountain]-wave [river] raged mightily" (FAULKES, 1995, p. 84), que fala sobre a violência com que o rio fluía, o que não descarta a possibilidade de leitura do rio como opressor, mas ainda assim se constitui como empobrecimento originário de adoção particular de termo.

O trecho "Com suas cabeças acima da água" e "Até que, ó mulher!" não têm correspondência na tradução de Faulkes. Não se encontra correspondência para "A dama que melhora tristezas", dito a respeito de Iddun, na tradução de Faulkes, em que apenas descobrimos ser esta a cuidadora das maçãs responsáveis pela cura da velhice dos Æsir. E o trecho em Faulkes, "Compare the verse written above 'It is beyond expectation that there could be born..." não encontra referência na tradução de Avelar, que acompanha a primeira apenas na menção de Thiodolf: "As Thiodolf said” (FAULKES, 1995, p. 90), "Até mesmo como Thjódólfr cantou".

Há liberdade tradutória no trecho "Com esse pequeno galho, / E sem escudo / Foi capaz de resistir", em que se sabe que, pelo mito, estava sem escudo e com apenas um cajado, que foi traduzido como "pequeno galho". Nota-se também que é dito não haver falta de suporte, "No lack of support", mas a menção do escudo não é feita, constituindo outro empobrecimento qualitativo influenciador das cadeias subjacentes de significado.

O trecho "Pela crista da boca de Rán" parece não condizer com o equivalente "out of white Ran's mouth", que poderia ser traduzido por "pela branca boca de Ran", porém este é um caso de tradução poética metafrástica, em que o tradutor optou pela interpretação da crista da boca de Ran, bruma do mar, como branca boca, optando-se por enriquecimento da tradução ao usar de referência do mar para falar de Ran, a ele relacionado. 
A menção de magia na Edda em prosa é traduzida como "negra" por Avelar em "habilidoso em magia negra", "skilled in magic" (FAULKES, 1995, p. 99). Já o trecho "e Gunnarr, e Högni fez juramentos de fraternidade" pode dar a entender que apenas Hogni fez juramento, porém é dito que ambos fizeram, sendo necessária a flexão adequada.

Nas traduções "Atli, filho de Budli" e "filhos de Gjúki", Avelar busca domesticar a formação de sobrenomes nórdicos ao público falante de português, traduzindo Budlason e Giukins, estratégia de domesticação caracterizada pela expansão de termos.

O trecho da tradução de Avelar "Devido a isso cotas de malha são chamadas de Roupas ou Vestes de Hamdir e Sörli" não tem referente na tradução que usamos como base comparativa.

Há inversão da ordem de apresentação de poemas na seção Skáldskaparmál de Avelar. O trecho "And on the island, instead of the Vidrir" aparece antes do trecho "This attack can be perceived on the penny", sendo um dos que não constituem omissão, mas inversão de ordem (FAULKES, 1995, p. 123). Artur Avelar ainda altera a ordem da tradução, colocando os kenningar sobre ursos e Hart depois do poema Alvinnsmal (FAULKES, 1995, p. 136).

Há uso de trecho do poema de Arnor sobre earls e o mar. Na tradução de Avelar o mesmo acontece, porém em cada ocorrência a tradução foi diferente, sendo a segunda mais coerente, apesar de gerar inconsistência. Segundo caso: "Que os homens ouçam como o Rei dos Earls, / De espírito forte, perseguiu o Mar; / O avassalador governante / Não cessou de se opor ao Oceano"; primeiro caso: "Deixe que os homens ouçam como o Rei dos Earls, / De espírito aguçado, procurou o mar; / O avassalador governante / Falhou em contrariar o oceano", para "Let the court learn how the keen-spirited king of earls pursued the sea, the irresistible prince did not cease to oppose the ocean" (FAULKES, 1995, p. 139). O mesmo ocorre no trecho "Gymir's spray-cold spae-wife [Ran] often brings the twisted-rope-bear [ship] into Ægir's [ocean's] jaws when the wave breaks” (Idem, 1995, p. 140), para o qual Artur Avelar traz duas traduções diferentes: "A gélida mulher de Gymir / Frequentemente traz o navio de cabos trançados / Direto para as mandíbulas de Ægir, / Onde as ondas se quebram", e "A esposa do Invernal Gymir / Traz o Urso de Cabos Trançados / Muitas vezes para as largas mandíbulas de Ægir, / Onde as raivosas ondas se quebram", em que a primeira parece mais adequada por conter menor adição de vocábulos não constantes no original. Isto é, na segunda, tem-se adição de "muitas vezes", embora no que diz respeito à tradução de "twisted-rope-bear", a segunda se mostre mais próxima ao kenning do original, cada qual com seus ganhos. Assim, a variação mostra como a tradução é ato individual, dependente de um contexto, podendo ser diferente em cada caso a se valer de objetivos ou fontes distintas.

"By means of these expressions battle shall be referred to in terms of swords or other weapons or shields" (FAULKES, 1995, p. 154) é um trecho omitido na tradução de Avelar. Entre outras omissões temos "clamourer" e "quiet", omitidos na tradução de Avelar para "swords" (Idem, 1995, p. 158). Ainda Hödr e Bragi são colocados entre os 
filhos de Odin na tradução de Avelar, mas na de Faulkes o trecho dos filhos termina em Heimdall e Sæming. E “[Marne, Móda, Thrym]” se constitui como um trecho a mais na tradução do Nafnapulur de Avelar.

Em ambas traduções “and”, em "Grábakr and Grafvölludr” e em “Ófnir and Sváfnir" não foi traduzido, ficando em inglês, erro na tradução.

O sumário de figuras vem após o Nafnapulur. Ao fim dele vem a seção chamada "Table of contents", com um sumário de todos os capítulos da obra, inclusive Notas do editor; há lista de livros publicados e contato. O sumário traz os nomes das obras em português e no original, além da fonte de onde foram obtidas, ano e nomes dos autores. Há erro na referência à obra "Thor na Luva de Skyrmir", que deveria ser "Skrymir" (Imagem 49). O link de cada obra de arte é compartilhado, sendo 116 imagens com apenas duas repetições, como a de Loki e Sygin, e uma entre as de Odin.

Nessa tradução optou-se pela domesticação, inclusive ortográfica, tendo-se d no lugar de ð e ö em vez de $\mathbf{q}$ (Nidhöggr para Níðhø̨gr), também th no lugar de p.

Inicialmente, a primeira tradução, Gylfaginning: a ilusão de Gylfi, traz uma introdução sobre a vida de Snorri, porém de forma mais resumida em comparação à última tradução, sem detalhar o lugar de nascimento e outros fatos da vida de Snorri.

Alguns erros não são partilhados entre as duas traduções, como o uso da palavra ausência sem acento, visto apenas na segunda versão.

Em alguns casos o texto explicita sujeitos ocultos, como em "da qual fundia o ouro", na primeira tradução, para "da qual ele fundia o ouro", na segunda, um caso de racionalização. Ainda no que concerne a linguagem, a primeira tradução, em relação à segunda, traz apresentação diferente no trecho "de tão abundante era este metal", em que falta o uso do "que"; também na apresentação de Príamo (segunda tradução) como Príamo e Príamos em diferentes ocorrências na primeira.

A primeira tradução evidencia maior preocupação com o entendimento dos mitos, optando o tradutor por domesticação ao traduzir "berserkers" por "guerreiros", em comparação à segunda, que mantém o termo original, consolidando-se assim como estrangeirização e apontando ao fator interpretativo na produção tradutória.

A apresentação de Noite, Dia, Lua e Sol na segunda tradução mostra a intenção tradutória de aproximar o leitor do vocabulário nórdico, optando pela domesticação seguida de estrangeirização em trechos como "chamada de Noite, ou Nótt"; "Dia, ou Dagr"; "Máni, ou Lua" e "Sol, ou Sól”, em oposição às apresentações da primeira tradução, que adota domesticação apenas, com "Noite", "Dia", "Lua" e "Sol". Nota-se que a segunda tradução promove ao mesmo tempo clarificação e expansão. Outro caso de estrangeirização após a domesticação é observado na apresentação dos Elfos Claros e Elfos Negros na segunda tradução em oposição à primeira, que adota apenas a domesticação - respectivamente: "Elfos Claros ou Ljósálfar, mas os Elfos Negros, ou Dökkálfar" e "Elfos Claros, mas os Elfos Negros". O mesmo acontece na apresentação do Inverno, Vetr, e na apresentação das Luvas de Ferro [“Járngóflar”]. 
Terra, no sentido de planeta, é deixado em caixa-baixa com frequência na primeira tradução, o que é corrigido na segunda, em que temos distinção entre terra (material, solo) e Terra (planeta).

A primeira tradução fala sobre "A Separação de Thor e Útgarda-Loki", mas na segunda, mais coerente, tem-se "Despedida", favorecendo o não empobrecimento das cadeias de significação da obra. E, se na primeira tradução, Bragi é apresentado como "dos poetas", na segunda é apresentado como "dos escaldos", por estratégia de estrangeirização. Já o navio de Freyr, que na primeira tradução cabe numa bolsa após ser dobrado, na segunda cabe no "bolso".

Outros detalhes apresentados na seção da segunda tradução de Artur Avelar podem ser observados também no que diz respeito à Ilusão de Gylfi. Algumas particularidades de ambas traduções ainda são notadas, sendo apresentadas na tabela a seguir à luz da tradução de Faulkes e acompanhadas por comentários relativos à análise da tradução.

\begin{tabular}{|c|c|c|}
\hline Tradução de Avelar & Tradução de Faulkes & Comentários \\
\hline “eras” (G2014) & "winters" (1995, p. 11) & $\begin{array}{l}\text { Caso de empobrecimento } \\
\text { qualitativo com adoção de ter- } \\
\text { mo menos poético ao contexto } \\
\text { e que não se relaciona às cama- } \\
\text { das de sentido subjacentes } \\
\text { à obra original. Na mitologia } \\
\text { nórdica os invernos são signi- } \\
\text { ficativos à contagem do tempo, } \\
\text { como "anos". }\end{array}$ \\
\hline $\begin{array}{l}\text { "E as águas sagradas uivam" } \\
\text { (G2014) }\end{array}$ & $\begin{array}{l}\text { "holy waters boil" (1995, } \\
\text { p. 18) }\end{array}$ & $\begin{array}{l}\text { Sua tradução mostra-se poética } \\
\text { no trecho, com o verbo uivar } \\
\text { como referência a ferver, ten- } \\
\text { do-se abandono do original em } \\
\text { favor da criatividade poética. }\end{array}$ \\
\hline $\begin{array}{l}\text { "Mas Odin deu o hidromel de } \\
\text { Suttungr aos Æsir e aos ho- } \\
\text { mens que possuem a capacida- } \\
\text { de de compor" (S2014) }\end{array}$ & & $\begin{array}{l}\text { Não é explicitado o fato de se } \\
\text { tratar da capacidade de com- } \\
\text { posição de poesia, o que não } \\
\text { impede o entendimento, mas } \\
\text { também não provê o leitor } \\
\text { iniciante com informações da } \\
\text { literatura. }\end{array}$ \\
\hline "Metáfora e métrica" (S2014) & $\begin{array}{l}\text { "Language and verse- } \\
\text { forms" }(1995, \text { p. } 64)\end{array}$ & $\begin{array}{l}\text { Embora não tenhamos apenas } \\
\text { metáforas como "linguagem" } \\
\text { da poesia, aquelas também são } \\
\text { relacionáveis a esta, sendo mé- } \\
\text { trica uma forma de entender } \\
\text { formas de versos ou "versifi- } \\
\text { cação". }\end{array}$ \\
\hline
\end{tabular}




\begin{tabular}{|c|c|c|}
\hline $\begin{array}{l}\text { "chamar tudo pelo seu nome" } \\
\text { (S2014) }\end{array}$ & & $\begin{array}{l}\text { É usado para tratar de "substi- } \\
\text { tuição", que não constitui me- } \\
\text { táfora, mas sim uma linguagem } \\
\text { poética, sendo mais adequado } \\
\text { o último termo. }\end{array}$ \\
\hline "Paráfrase" (S2014) & “kenning” (1995) & \\
\hline $\begin{array}{l}\text { "e Heleno e os Æsir chamam } \\
\text { de Ale" (G2014) }\end{array}$ & & $\begin{array}{l}\text { Deveríamos, na verdade, ter "e } \\
\text { Heleno, os Æsir o chamam de } \\
\text { Ale". }\end{array}$ \\
\hline $\begin{array}{l}\text { "Ele veio de Tróia e criou por } \\
\text { isso grandes obras" (S2014) }\end{array}$ & $\begin{array}{l}\text { "he escaped from Troy } \\
\text { and later achieved great } \\
\text { deeds" (1995, p. 66) }\end{array}$ & $\begin{array}{l}\text { Esse trecho da tradução de } \\
\text { Avelar traz implicação sintática } \\
\text { de causalidade, uma necessida- } \\
\text { de não encontrada na tradução } \\
\text { de Faulkes, dando ao leitor } \\
\text { a ideia relacional de grandes } \\
\text { feitos serem associados ao lo- } \\
\text { cal de origem, não apenas ao } \\
\text { agente. }\end{array}$ \\
\hline $\begin{array}{l}\text { "Deus dos enforcados" } \\
(\mathrm{S} 2014)\end{array}$ & $\begin{array}{l}\text { "Hanged-god" (1995, p. } \\
66)\end{array}$ & $\begin{array}{l}\text { Aqui não se trata de deus de } \\
\text { determinadas pessoas, "en- } \\
\text { forcados", e sim sobre o deus } \\
\text { "pendurado", Odin, sendo } \\
\text { "pendurado-deus" possibilida- } \\
\text { de. }\end{array}$ \\
\hline "paciente" (S2014) & $\begin{array}{l}\text { "deserted wife" [Earth] } \\
(1995)\end{array}$ & $\begin{array}{l}\text { Vê-se incoerência semântica } \\
\text { tradutória em supor a possibi- } \\
\text { lidade de espera a Frigg como } \\
\text { "deserted-wife", quando, na } \\
\text { verdade, esta concepção é uti- } \\
\text { lizada a Terra, "abandonada" } \\
\text { por Odin. }\end{array}$ \\
\hline "Doador de Terras" (S2014) & "Land-getter" (1995) & $\begin{array}{l}\text { Da tradução de Faulkes, nota- } \\
\text {-se tratar-se de "conquistador } \\
\text { de terras". }\end{array}$ \\
\hline $\begin{array}{l}\text { "a linhagem dos filhos de } \\
\text { Odin" (S2014) }\end{array}$ & $\begin{array}{l}\text { "Vidrir's [Odin's] heir's } \\
\text { [Thor's] line" (1995, p. 72) }\end{array}$ & $\begin{array}{l}\text { A tradução ao português não } \\
\text { trouxe ao leitor o entendimen- } \\
\text { to de ter-se "a linhagem do Fi- } \\
\text { lho de Odin [Thor]", como es- } \\
\text { perado da tradução de Faulkes. }\end{array}$ \\
\hline “coração de pedra” (S2014) & $\begin{array}{l}\text { "power-stone [heart]" } \\
(1995, \text { p. } 72)\end{array}$ & $\begin{array}{l}\text { Ao invés de tratar-se de cora- } \\
\text { ção composto de pedra, real ou } \\
\text { metafórico, trata-se da "pedra } \\
\text { poderosa", o coração. }\end{array}$ \\
\hline
\end{tabular}




\begin{tabular}{|c|c|c|}
\hline "braços prontos" (S2014) & $\begin{array}{l}\text { "arm's mouth [fist]" } \\
(1995, \text { p. } 74)\end{array}$ & $\begin{array}{l}\text { Apesar de tratar-se de punhos, } \\
\text { "fist", a tradução de Avelar } \\
\text { traz, com "braços", possibilida- } \\
\text { de metafórica. }\end{array}$ \\
\hline $\begin{array}{l}\text { "Habitante Divino das Mora- } \\
\text { das dos Pais" (S2014) }\end{array}$ & $\begin{array}{l}\text { "father's homestead-inha- } \\
\text { biting" (1995, p. 76) }\end{array}$ & $\begin{array}{l}\text { Outro caso de flexão inadequa- } \\
\text { da. }\end{array}$ \\
\hline $\begin{array}{l}\text { "Uma parte caiu por terra, e } \\
\text { dela vieram as montanhas de } \\
\text { pedra" (S2014) }\end{array}$ & $\begin{array}{l}\text { "whetstone rocks" (1995, } \\
\text { p. } 79)\end{array}$ & $\begin{array}{l}\text { Temos aqui a incoerência de } \\
\text { tratar montanhas de pedra } \\
\text { como tradução para "pedras } \\
\text { de afiar", que teria sentido e } \\
\text { função diferentes às de pedras } \\
\text { comuns. }\end{array}$ \\
\hline $\begin{array}{l}\text { "de forma que seu pé ficou } \\
\text { em cima do pescoço de Thor" } \\
\text { (S2014) }\end{array}$ & $\begin{array}{l}\text { "and he fell towards over } \\
\text { Thor so that his leg lay } \\
\text { across Thor's neck" (1995, } \\
\text { p. } 79)\end{array}$ & $\begin{array}{l}\text { Esse se constitui como mais } \\
\text { um caso em que um referente } \\
\text { foi trocado por outro próximo, } \\
\text { mas de distinta função. Comum } \\
\text { a casos com "água" e "braços" } \\
\text { também. }\end{array}$ \\
\hline “Esposa de Odin” (S2014) & $\begin{array}{l}\text { "Svolnir's widow" (1995, } \\
\text { p. 80) }\end{array}$ & $\begin{array}{l}\text { Ao falar de Earth, "viúva", con- } \\
\text { forme a tradução de Faulkes, } \\
\text { seria mais adequado. }\end{array}$ \\
\hline $\begin{array}{l}\text { "Então os deuses desejaram } \\
\text { / E também desejaram as Val- } \\
\text { quírias" (S2014) }\end{array}$ & $\begin{array}{l}\text { "The bonds [gods] caused } \\
\text { this, the ladies of the } \\
\text { fray [valkyries] wished it" } \\
(1995, \text { p. } 80)\end{array}$ & $\begin{array}{l}\text { Embora tenha sido atribuído a } \\
\text { ambos pela tradução de Avelar, } \\
\text { o referente diz respeito apenas } \\
\text { às valquírias, tendo os deuses } \\
\text { "causado" o evento. }\end{array}$ \\
\hline $\begin{array}{l}\text { "tanto que o amolador / De } \\
\text { aços, presa" (S2014) }\end{array}$ & & $\begin{array}{l}\text { Em outro caso de falta de re- } \\
\text { visão, deveríamos ter "preso". }\end{array}$ \\
\hline $\begin{array}{l}\text { "Então Loki foi levado e trazi- } \\
\text { do" (S2014) }\end{array}$ & $\begin{array}{l}\text { "Loki was captured there } \\
\text { and brought to giant Geir- } \\
\text { rod" (1995, p. } 81)\end{array}$ & $\begin{array}{l}\text { Esse trecho da tradução de } \\
\text { Avelar adota dois verbos que } \\
\text { passam a ideia de que Loki foi } \\
\text { levado a determinado lugar e } \\
\text { após trazido de volta, o que não } \\
\text { corresponde à ideia do original. } \\
\text { Isso poderia ter sido evitado } \\
\text { com "Então Loki foi capturado } \\
\text { e trazido", opção mais adequa- } \\
\text { da a uma tradução mais literal. }\end{array}$ \\
\hline "Não tão confiante" (S2014) & $\begin{array}{l}\text { "The not very trustwor- } \\
\text { thy" (1995, p. } 83)\end{array}$ & $\begin{array}{l}\text { Adoção mais adequada de vo- } \\
\text { cabulário poderia ter sido feita } \\
\text { a partir de "confiável". }\end{array}$ \\
\hline
\end{tabular}




\begin{tabular}{|c|c|c|}
\hline $\begin{array}{l}\text { "Os gigantes estavam ansiosos } \\
\text { por esmagar / Os descenden- } \\
\text { tes de Thor" (S2014) }\end{array}$ & $\begin{array}{l}\text { "they were eager to crush } \\
\text { Thorn's kin [giants]" } \\
(1995, \text { p. } 83)\end{array}$ & $\begin{array}{l}\text { Há erro na tradução de Thorn } \\
\text { por Thor. A falta do "n" dá a } \\
\text { um leitor sem referência do } \\
\text { original a impressão de que os } \\
\text { gigantes queriam esmagar os } \\
\text { descendentes de Thor, quando } \\
\text { é dito que Loki e Thor estavam } \\
\text { ansiosos por esmagar os gigan- } \\
\text { tes, sendo Thorn um deles. }\end{array}$ \\
\hline $\begin{array}{l}\text { "Havia uma sombria perturba- } \\
\text { ção da paz" (S2014) }\end{array}$ & $\begin{array}{l}\text { "That was a black dis- } \\
\text { turbance of the peace" } \\
(1995, \text { p. } 85)\end{array}$ & $\begin{array}{l}\text { Optando por estratégia para- } \\
\text { frástica, Avelar passa o refe- } \\
\text { rente de um pronome demons- } \\
\text { trativo para o verbo haver, } \\
\text { o que poderia ser entendido } \\
\text { como deformação de racio- } \\
\text { nalização, segundo Berman } \\
\text { (2000) na alteração de um ver- } \\
\text { bo a substantivo e vice-versa. }\end{array}$ \\
\hline $\begin{array}{l}\text { "Foram pressionados os vastos } \\
\text { olhos / De Gjálp e Greip / } \\
\text { Conto o alto teto" (S2014) }\end{array}$ & “against” (1995) & $\begin{array}{l}\text { Outro erro gerado por falta de } \\
\text { revisão. }\end{array}$ \\
\hline $\begin{array}{l}\text { "A gigante das montanhas / } \\
\text { Não estava acostumada a ser } \\
\text { tímida" (S2014) }\end{array}$ & & $\begin{array}{l}\text { Incomum é a atribuição de } \\
\text { covardia e personagens de } \\
\text { sexo feminino na Edda, não } \\
\text { sendo claro de onde vem tal } \\
\text { referência do tradutor. }\end{array}$ \\
\hline $\begin{array}{l}\text { "Hœnir foi o escolhido para } \\
\text { soprar o fogo" (S2014) }\end{array}$ & $\begin{array}{l}\text { "The raven-god's [Odin's] } \\
\text { friend [Loki] had to blow } \\
\text { [the fire]" (1995, p. } 87)\end{array}$ & $\begin{array}{l}\text { Apesar de ser dito que Hœnir } \\
\text { soprou o fogo na tradução } \\
\text { de Avelar, Loki é escolhido a } \\
\text { fazê-lo. }\end{array}$ \\
\hline $\begin{array}{l}\text { "O gigante, ansioso para matar, } \\
\text { / Afundou-se / Onde os deu- } \\
\text { ses desavisados, / Odin, Loki } \\
\text { e Hœnir estavam sentados" } \\
\text { (S2014) }\end{array}$ & $\begin{array}{l}\text { "where the guileless de- } \\
\text { fenders of gods were sit- } \\
\text { ting" }(1995, \text { p. } 87)\end{array}$ & $\begin{array}{l}\text { Há incoerência em dizer que os } \\
\text { deuses estavam "desavisados", } \\
\text { uma vez que é dito na Edda em } \\
\text { prosa que "os honestos defen- } \\
\text { sores dos deuses estavam sen- } \\
\text { tados" [tradução nossa]. }\end{array}$ \\
\hline "besta" (S2014) & “ox” (1995, p. 87) & \\
\hline $\begin{array}{l}\text { "Com as asas de uma água" } \\
\text { (S2014) }\end{array}$ & & $\begin{array}{l}\text { Erro tipográfico em que de- } \\
\text { víamos ter "Com as asas de } \\
\text { uma águia". }\end{array}$ \\
\hline
\end{tabular}




\begin{tabular}{|c|c|c|}
\hline $\begin{array}{l}\text { "No pedestal do anão" [na } \\
\text { menção a Finn] (S2014) }\end{array}$ & $\begin{array}{l}\text { "This is depicted on my } \\
\text { mountain-Finn's [giant's, } \\
\text { Hrugnir's] sole-bridge } \\
\text { [pedestal, shield]" (1995, } \\
\text { p. 88) }\end{array}$ & $\begin{array}{l}\text { Apesar de Finn ser um anão, o } \\
\text { escudo comentado no trecho } \\
\text { pertence ao gigante. }\end{array}$ \\
\hline $\begin{array}{l}\text { "Assim cantou o escaldo de } \\
\text { Earl Arnórr" (S2014) }\end{array}$ & & $\begin{array}{l}\text { O trecho pode levar o leitor } \\
\text { a entender que o poema a se- } \\
\text { guir seria do escaldo "de Earl } \\
\text { Arnórr", gerando um genitivo, } \\
\text { porém, o poeta de earl, Arnor, } \\
\text { é quem cantou o poema. Em } \\
\text { outro trecho da tradução esse } \\
\text { escaldo é apresentado como } \\
\text { "Arnórr Jarlaskáld". }\end{array}$ \\
\hline “Bödvarr Balti” (S2014) & “Kolli” (1995) & \\
\hline "Hefring, Udr" (S2014) & "Hefring, Unn" (1995) & \\
\hline $\begin{array}{l}\text { "Primeiro começou a voar, / } \\
\text { Os feios filhos de Fornjortr" } \\
\text { (S2014) }\end{array}$ & $\begin{array}{l}\text { "Forniot's ugly sons } \\
\text { began first to send snow" } \\
(1995, \text { p. } 93)\end{array}$ & $\begin{array}{l}\text { No trecho de Avelar há incor- } \\
\text { reção em dizer que os feios } \\
\text { filhos de Forniot começaram } \\
\text { a voar, não a mandar neve, e } \\
\text { ainda mais em fazê-lo em dis- } \\
\text { cordância de número. }\end{array}$ \\
\hline “Agulhas de Glasir” (S2014) & $\begin{array}{l}\text { "Glasir's foliage" (1995, } \\
\text { p. 94) }\end{array}$ & \\
\hline $\begin{array}{l}\text { "Fogo de todas as Águas e de } \\
\text { Mão, Pedra e Recife ou Brilho } \\
\text { das Mãos" (S2014) }\end{array}$ & $\begin{array}{l}\text { "fire of all kinds of waters } \\
\text { and of the arm", "stones } \\
\text { and rocks or gleam of the } \\
\text { arm" (1995, p. } 95)\end{array}$ & $\begin{array}{l}\text { Entre outros exemplos, "arm" } \\
\text { foi traduzido por "mão", não } \\
\text { braço, trazendo ao texto efeito } \\
\text { parafrástico. }\end{array}$ \\
\hline “Fogo das Águas" (S2014) & $\begin{array}{l}\text { "fire of lakes" (1995, p. } \\
95)\end{array}$ & $\begin{array}{l}\text { Embora na explicação de ale- } \\
\text { gorias Avelar fale da relação } \\
\text { de água para mar, rio para la- } \\
\text { gos, e oceano para rio, "lakes" } \\
\text { é traduzido nesse trecho por } \\
\text { "águas", de modo mais geral. }\end{array}$ \\
\hline "Sindri" (S2014) & “Eitri” (1995, p. 96) & \\
\hline "bolsa" (S2014) & $\begin{array}{l}\text { "pocket” [of Freyr] (1995, } \\
\text { p. } 97)\end{array}$ & \\
\hline $\begin{array}{l}\text { "brilhante fita de Fulla" } \\
\text { (S2014) }\end{array}$ & $\begin{array}{l}\text { "Fulla's eyelashes" (1995, } \\
\text { p. 98) }\end{array}$ & \\
\hline
\end{tabular}




\begin{tabular}{|c|c|c|}
\hline $\begin{array}{l}\text { "Cílios de Chuva de sua mãe" } \\
\text { (S2014) }\end{array}$ & $\begin{array}{l}\text { "her mother's eyelash-rain } \\
\text { [tears]" (1995, p. } 98)\end{array}$ & $\begin{array}{l}\text { Em outro trecho traduz-se } \\
\text { "eyelashes", ao invés de cílios, } \\
\text { por sobrancelhas (FAULKES, } \\
\text { 1995, p. 99). }\end{array}$ \\
\hline "Resgate da Lontra" (S2014) & $\begin{array}{l}\text { “otter-payment” (1995, p. } \\
100)\end{array}$ & \\
\hline $\begin{array}{l}\text { "embalou-o em dois sacos" } \\
\text { (S2014) }\end{array}$ & $\begin{array}{l}\text { "tied it in packs" (1995, p. } \\
102)\end{array}$ & $\begin{array}{l}\text { Da incerteza do número de sa- } \\
\text { cos no mito pela tradução de } \\
\text { Faulkes passa-se à menção de } \\
\text { "dois" por Avelar. }\end{array}$ \\
\hline “canção de louvor” (S2014) & $\begin{array}{l}\text { "in the drápa" (1995, p. } \\
\text { 107) }\end{array}$ & $\begin{array}{l}\text { Caso de domesticação em que } \\
\text { se optou pela função do termo } \\
\text { a ser traduzido. }\end{array}$ \\
\hline “César Augusto" (S2014) & $\begin{array}{l}\text { "emperor Augustus" } \\
(1995, \text { p. 107) }\end{array}$ & \\
\hline $\begin{array}{l}\text { "Fródi era o mais poderoso } \\
\text { de todos os reis das terras do } \\
\text { norte, a paz era chamada pelo } \\
\text { seu nome onde quer que a lín- } \\
\text { gua dinamarquesa era falada" } \\
\text { (S2014) }\end{array}$ & $\begin{array}{l}\text { "Frodi was the greatest of } \\
\text { all the kings in northern } \\
\text { countries, the peace was } \\
\text { attributed to him through- } \\
\text { out all Scandinavia" (1995, } \\
\text { p. 107) }\end{array}$ & $\begin{array}{l}\text { Embora seja dito que o nome } \\
\text { de "Fródi" era usado para a paz } \\
\text { onde quer que a língua dina- } \\
\text { marquesa fosse falada, o refe- } \\
\text { rente na tradução de Faulkes é } \\
\text { a Escandinávia como um todo. }\end{array}$ \\
\hline “E é esse seu início" (S2014) & & $\begin{array}{l}\text { Avelar adicionou esse trecho, } \\
\text { não constante na tradução de } \\
\text { Faulkes }(1995, \text { p. 107), após "É } \\
\text { dito que elas cantaram a canção } \\
\text { que é chamada de Canção de } \\
\text { Grótti". }\end{array}$ \\
\hline "Hleidr" (S2014) & “Lejre" (1995, p. 109) & \\
\hline "Rei de Lurid" (S2014) & $\begin{array}{l}\text { "prince of Lund" (1995, } \\
\text { p. 113) }\end{array}$ & \\
\hline $\begin{array}{l}\text { "Hermódr do lar da serpente" } \\
\text { (S2014) }\end{array}$ & $\begin{array}{l}\text { "that sword-lair [shield] } \\
\text { Hermod" (1995, p. 114) }\end{array}$ & \\
\hline $\begin{array}{l}\text { "O Lança-Ouro se faz leal a } \\
\text { ele, / Sua guarda com armadu- } \\
\text { ra real" (S2014) }\end{array}$ & $\begin{array}{l}\text { "With a prince's deeds the } \\
\text { gold-thrower makes his } \\
\text { court loyal to himself" } \\
(1995, \text { p. } 114)\end{array}$ & $\begin{array}{l}\text { O trecho da tradução de Avelar } \\
\text { à Edda em prosa não transmite } \\
\text { com clareza a ideia de que o } \\
\text { lançador de ouro, o rei, com os } \\
\text { feitos de um príncipe faz sua } \\
\text { corte leal a si, como apresenta- } \\
\text { do por Faulkes. }\end{array}$ \\
\hline $\begin{array}{l}\text { "A Bebida das Baleias é o mar" } \\
\text { (S2014) }\end{array}$ & $\begin{array}{l}\text { "The land of whales is the } \\
\text { sea" (1995, p. 115) }\end{array}$ & $\begin{array}{l}\text { Na tradução de "land" por "be- } \\
\text { bida", Avelar faz uso parafrás- } \\
\text { tico da linguagem em prol de } \\
\text { uma tradução poética. }\end{array}$ \\
\hline
\end{tabular}




\begin{tabular}{|c|c|c|}
\hline $\begin{array}{l}\text { "Tu, feroz Pilastra de Guerra, } \\
\text { segurou / Dois reis, teus terri- } \\
\text { tórios / Com a força de heróis, } \\
\text { onde os corvos / Não passa- } \\
\text { ram fome; belo coração tens" } \\
\text { (S2014) }\end{array}$ & $\begin{array}{l}\text { "You are quick to act } \\
\text { against mankind" (1995, } \\
\text { p. 117) }\end{array}$ & $\begin{array}{l}\text { O trecho apresenta pessoa que } \\
\text { tem por impulso agir contra } \\
\text { os humanos; a tradução para } \\
\text { o português aqui estudada, po- } \\
\text { rém, traz ideia oposta, apresen- } \\
\text { tando "belo coração". Segundo } \\
\text { comentário do editor, podemos } \\
\text { entender isso como uma ironia } \\
\text { do tradutor. Essa explicação } \\
\text { me pareceu pouco provável a } \\
\text { princípio por não haver recor- } \\
\text { rência de ironia na tradução, } \\
\text { mas ainda assim, pode ser con- } \\
\text { siderada. }\end{array}$ \\
\hline $\begin{array}{l}\text { "Terra do Círculo" (S2014) } \\
\text { "Anel da Terra" (S2014) }\end{array}$ & "circle" (1995) & \\
\hline “Urdr" (S2014) & "Weird" (1995, p. 121) & \\
\hline “Heiti” (S2014) & "Heidi" (1995, p. 126) & \\
\hline “Amigo de Deus" (S2014) & “God's son” (1995, p. 127) & \\
\hline "homens de Gardar" (S2014) & “Russians" (1995, p. 127) & \\
\hline “Jerusalém” (S2014) & "Palestine" (1995, p. 128) & \\
\hline $\begin{array}{l}\text { "Gigantes de Gelo de Sýr" } \\
\text { (S2014) }\end{array}$ & & $\begin{array}{l}\text { Embora a tradução de Avelar } \\
\text { relacione os gigantes de Gelo } \\
\text { a Syr, nenhuma referência ex- } \\
\text { plícita como essa é dada em } \\
\text { Faulkes }(1995, \text { p. } 131) \text {. }\end{array}$ \\
\hline $\begin{array}{l}\text { "O Pai de Oláfr / Aumen- } \\
\text { ta a tempestade de Járnsaxa" } \\
\text { (S2014) }\end{array}$ & $\begin{array}{l}\text { "Every difficulty increases } \\
\text { Iarnsaxa's wind [courage] } \\
\text { in Olaf's father, so that } \\
\text { praise is due" (1995, p. } \\
\text { 131) }\end{array}$ & $\begin{array}{l}\text { Cada dificuldade, não o pai de } \\
\text { Oláfr, aumenta a tempestade. }\end{array}$ \\
\hline “Götha” (S2014) & $\begin{array}{l}\text { "cold Elbe" (1995, p. 135) } \\
\text { "Elfr" (2012, p. 223) }\end{array}$ & \\
\hline “Hýrr” (S2014) & “Høfir" (2012, p. 229) & \\
\hline $\begin{array}{l}\text { "Você traz da bela Noruega" } \\
\text { (S2014) }\end{array}$ & $\begin{array}{l}\text { "You fitted out a fleet" } \\
(1995, \text { p. } 140)\end{array}$ & \\
\hline $\begin{array}{l}\text { "cardume" (S2014) } \\
\text { "ameaçador" (idem) } \\
\text { "Unidade" (idem) } \\
\text { "joia" (idem) } \\
\text { "Sinal Luminoso" (idem) } \\
\text { "incêndio" (idem) }\end{array}$ & $\begin{array}{l}\text { "Offing” (1995, p. 142) } \\
\text { "shoal" (1995) } \\
\text { "thunderer" (idem) } \\
\text { "sparkler" (idem) } \\
\text { "Blaze" (idem) } \\
\text { "Lowe" (idem) }\end{array}$ & \\
\hline
\end{tabular}




\begin{tabular}{|c|c|c|}
\hline $\begin{array}{l}\text { "Os anos chamam de Narrador } \\
\text { dos Sonhos" (S2014) }\end{array}$ & & $\begin{array}{l}\text { Embora o texto apresente a } \\
\text { palavra "anos", trata-se de } \\
\text { "anões". }\end{array}$ \\
\hline $\begin{array}{l}\text { "Eymundr de Hólmgardr" } \\
\text { (S2014) }\end{array}$ & $\begin{array}{l}\text { "Emund of Novgorod" } \\
(1995, \text { p. 146) } \\
\text { "King Emund of Hol- } \\
\text { mgarðr" (2012, p. 209) }\end{array}$ & \\
\hline "gangue" (S2014) & & $\begin{array}{l}\text { A tradução de "cops" como } \\
\text { gangue seria pouco indicada } \\
\text { pelo usual teor pejorativo da } \\
\text { palavra gangue ao português. }\end{array}$ \\
\hline $\begin{array}{l}\text { "Fidalga" (S2014) } \\
\text { "senhora" (idem) }\end{array}$ & $\begin{array}{l}\text { "ristil" (1995, p. 153) } \\
\text { "ryg" (idem) }\end{array}$ & $\begin{array}{l}\text { Esses termos poderiam ser } \\
\text { traduzidos por mulher (inde- } \\
\text { pendente) e fidalga, respectiva- } \\
\text { mente. }\end{array}$ \\
\hline "Tranças" (S2014) & "tresses" (1995, p. 153) & $\begin{array}{l}\text { A tradução não metafrástica } \\
\text { seria "longos cabelos", uma } \\
\text { vez que esse é o significado de } \\
\text { "tresses", sinônimo de "locks", } \\
\text { que remetem a madeixas não } \\
\text { necessariamente presas. Nota- } \\
\text {-se que o tradutor adotou me- } \\
\text { táfrase no uso de referente de } \\
\text { tranças, comum entre as mu- } \\
\text { lheres escandinavas (conforme } \\
\text { achados arqueológicos). }\end{array}$ \\
\hline “grãos" (S2014) & “corn" (1995) & \\
\hline $\begin{array}{l}\text { "Hostilidade, } \quad \text { Violência" } \\
\text { (S2014) }\end{array}$ & $\begin{array}{l}\text { "impulsiveness, impe- } \\
\text { tuousness" }(1995 \text {, p. 154) }\end{array}$ & \\
\hline $\begin{array}{l}\text { "Vídgrípr" (N2014) } \\
\text { "Gillingr" (idem) } \\
\text { "Skasi" (idem; apenas uma } \\
\text { ocorrência errada) }\end{array}$ & $\begin{array}{l}\text { "Vingrip" (1995, p. 157) } \\
\text { "Grimling" (1995, p. 157) } \\
\text { "Skadi” (1995) }\end{array}$ & \\
\hline $\begin{array}{l}\text { "Sul" (N2014) } \\
\text { "Oykill" (idem) "Idsvöl" } \\
\text { (idem) } \\
\text { "Lúcio" (idem) - domesticação } \\
\text { "Vermelho" (idem) - domesti- } \\
\text { cação } \\
\text { "Marta" (idem) -domestica- } \\
\text { ção } \\
\text { "Vetrlidi" (idem) - estrangeiri- } \\
\text { zação }\end{array}$ & $\begin{array}{l}\text { "Sudr" (1995, p. 161) } \\
\text { "Ekla" (idem) "Vidsvol" } \\
\text { (idem) } \\
\text { "Andvari" (1995, p. 162) } \\
\text { "Rufus" (1995, p. 163) } \\
\text { "Mord" (1995, p. 164) } \\
\text { "winter-survivor" (1995, } \\
\text { p. 164) }\end{array}$ & $\begin{array}{l}\text { Alguns nomes sofreram breves } \\
\text { adaptações, como Nid, Tholl, } \\
\text { Bro, Alin, Leiptr, Ormt, Yn, } \\
\text { Durathror, Heidthornir e Ska- } \\
\text { tyrnir, traduzidos por Avelar, } \\
\text { respectivamente, como Nith, } \\
\text { Thuil, Brora, Alne, Leiftr, Ar- } \\
\text { met, Inn, Dyratrhór, Heidthyr- } \\
\text { nir e Skattyrnir. }\end{array}$ \\
\hline
\end{tabular}




\begin{tabular}{|l|l|l|}
\hline "E o arado corte tão largo" & & \\
(G2013) & & \\
"E o arado cortou tão largo" & & \\
(G2014) & & \\
\hline "e ela parou em um determina- & & \\
do som" (G2013) & & \\
"determinado & & \\
(G2014) & & \\
\hline "E assim diz Bragi, o antigo & & \\
poema" (G2013) & & \\
"E assim diz Bragi, o antigo es- & & \\
caldo" (G2014) & & \\
\hline "Cinto de Força" (G2013) & Megingjarder & \\
"Cinturão de Força" (G2014) & & \\
\hline
\end{tabular}

Embora haja incorreções gramaticais e algumas adaptações, nota-se que poucas podem trazer prejuízo ao entendimento dos mitos ou da obra éddica, trazendo na realidade mais benefícios a leitores lusófonos interessados no tema, inclusive por trechos de criatividade poética e metafrástica, muitas vezes invocadas pelo original. Alguns contextos apenas mostram-se imprecisos e nebulosos ao adotar essa postura, o que pode levar a entendê-las como tendências deformacionais, conforme Berman. Entre as mais frequentes tem-se destruição de cadeias subjacentes de significação, clarificação e expansão. Houve revisão de trechos e textos da primeira tradução em relação à segunda, conforme se nota nos últimos exemplos da tabela da tradução de Avelar, e mudança no ato tradutório entre uma tradução e outra.

\section{Caminhos: de navegados a navegáveis}

Séculos após os escritos de Snorri, vemos um interesse crescente pela mitologia nórdica despontar. Nas últimas décadas, pesquisas na área têm crescido. Em matéria de mitologia nórdica no Brasil, como por exemplo no programa de Pós-graduação de Ciência das Religiões da Universidade Federal da Paraíba, os alunos têm como opção utilizar traduções em inglês ou em espanhol da Edda pela falta de uma tradução confiável e direta ao português. Os leitores sem afiliação acadêmica pouco sabem, também, sobre a existência de traduções da Edda ao português, e assim optam pela leitura de adaptações acessíveis e de maior divulgação.

O que essa pesquisa iniciada com o Professor John Lindow e acompanhada pelo Professor John Milton procura apresentar aos lusófonos é a existência de traduções da Edda ao português, suas principais características, desafios e contribuições para a área 
acadêmica, entendendo e validando cada ato tradutório em seu intento - pois, conforme Aubert (1994, p. 2), a tradução "jamais deve ser vista como inalcançável ou fadada ao fracasso". O ato tradutório é e sempre será possível, mas vale notar que "a cada ato tradutório, [será necessário] efetuar uma análise global da situação tradutória específica e das suas necessidades detectáveis, investigar a densidade e o grau de 'amarração' referencial de cada texto, e adotar uma determinada e consciente postura para, então, efetivar o ato tradutório resgatando o referente de partida, buscando seus equivalentes, aproximados no complexo língua/cultura de chegada, ou efetuando conciliações entre essas duas vertentes, recorrendo, eventualmente, a mecanismos de compensação, de natureza linguística, visual ou outra” (p. 52). Nesse sentido, vale ressaltar que, apesar dos termos pouco positivos, como empobrecimento ou destruição, adotados Berman, os atos tradutórios visitados não são e não devem ser vistos de forma negativa nesse trabalho, tratando-se apenas de termos da área usados para avaliação das estratégias domesticadoras empregadas pelos tradutores. O que temos a partir desse trabalho é um início ao desenvolvimento da área proporcionado por cinco traduções, cinco projetos de tradução, de obra e de leitor.

Em função do estilo, e das notas, pode-se dizer que a tradução acadêmica de Magalhães se coloca a um leitor exigente, que busque a união da forma ao conteúdo, tanto na prosa quanto na poesia, e a apreensão de informações e conhecimento através de mapas, glossário e notas.

Estrangeirismos mostraram a intenção tradutória de aproximar o leitor lusófono da cultura, da língua, da história e da literatura nórdica, porém com a particularidade de se ater inteiramente apenas ao prólogo e à "Ilusão de Gylfi”, não trazendo Skáldskaparmál. Quase impecável, há poucas incorreções, com apenas uma a afetar o entendimento das narrativas.

Reconhecimento deve ser dado às traduções de Moreira, que busca com estas aproximar leitores, principalmente internautas falantes de português da cultura e da religião nórdica. Ambas versões trazem a íntegra de Gylfaginning e trechos de Skáldskaparmál, mas apenas a mais recente traz trechos de Nafnapulur e o Prólogo. As incorreções gramaticais e de conteúdo inviabilizam o uso acadêmico dessas traduções, mas ambas se mostram relevantes a iniciantes no assunto, trazendo resumos de capítulos e de poemas e um índice de personagens com seus significados ou funções. A segunda tradução traz mais amplo material de apoio ao leitor, com mais casos de estrangeirização, aos quais traz informações esclarecedoras no índice de personagens. Há alguns casos que podem motivar confusão ou interpretações erradas ao leitor, mas estes seriam problemas na tradução e não de tradução.

Das cinco traduções analisadas, a mais recente, de Artur Avelar, mostra-se a mais completa e, se não fosse por algumas incorreções e certas faltas poéticas no que concerne os poemas, poderia ser usada academicamente. De todo modo, apresenta-se como boa leitura a um iniciado ou iniciante na aquisição de conhecimento da mitologia em questão. 
Apesar de não vir acompanhada de glossário ou notas, também apresenta uma introdução relevante e elenca obras em domínio público, o que a enriquece como tradução. O mesmo pode ser dito quanto aos pontos positivos e negativos da primeira tradução, esta centrada apenas no Prólogo e em Gylfaginning. A estrangeirização é mais frequente na segunda tradução, que costuma ser seguida de domesticação em apostos explicativos.

Nota-se que a eficácia das quatro últimas traduções estão de acordo com o propósito tradutório dos tradutores, que tinham por intenção o compartilhamento de informações e conhecimentos mitológicos com interessados em mitologia nórdica, sendo, portanto, um objetivo não acadêmico, assim como as traduções, que não obtiveram grande apoio editorial.

Apesar de a primeira tradução ser acadêmica, é pouco acessível, publicada em 1993 e não teve reedições nem se encontra disponível em livrarias. Há necessidade, ainda, de uma tradução acadêmica completa da Edda de Snorri que facilite aos lusófonos a inserção nessa área de estudos, o desenvolvimento de novos conhecimentos literários e culturais e a leitura mais fluida aos leitores por entretenimento, provendo-lhes do prazer da leitura e da sofisticação que remonta ao próprio estilo da Edda de Snorri, que se estabelece através da diversidade de gêneros literários e estilos, bem como do público dessa mitologia.

\section{Referências bibliográficas}

ARROJO, Rosemary. Oficina de tradução: a tradução na prática. São Paulo: Ática, 1986.

AUBERT, Francis Henrik. As (in)fidelidades da traducão: servidões e autonomia do tradutor. Campinas: Editora da Unicamp, 1994.

BASSNETT-MCGUIRE, Susan. Translation Studies. Routledge: London; New York, 1988. New Accents.

BERMAN, Antoine. "Translations and the trials of the foreign". In: VENUTI, Lawrence. The Translations Studies Reader. London; New York: Routledge, 2000.

HERMANNSSON, Halldór. Bibliography of the Eddas. 1920.

LANGER, Johnni (Org.). Dicionário de mitologia nórdica: símbolos, mitos e ritos. São Paulo: Hedra, 2015.

LINDOW, John. Norse Mythology: A Guide to Gods, Heroes, Rituals and Beliefs. 2001.

"Mitologia Viking" (anotações de aula de matéria de mesmo nome). University of New Mexico, Spring Semester, 2015.

NORD, Christiane. Translating as a Purposeful Activity: Functionalist Approaches Explained. Manchester, UK: St. Jerome Pub., 1997.

STURLUSON, Snorri. Edda. Tradução de FAULKES, Anthony. London: Everymen, 1995. 
. The Uppsala Edda. Tradução de FAULKES, Anthony. Edição de PÁLSSON, Heimir. Viking Society for Northern Research; University College London, 2012.

. Edda em prosa: textos da mitologia nórdica. Tradução de LIMA, Marcelo Magalhães. Rio de Janeiro: Numen, 1993.

. Gylfaginning: a ilusão de Gylfi. Tradução de AVELAR, Artur. Editora Barbudânia, 2013. Disponível em: Kindle. Acesso em: jun./2015.

. Gylfaginning e Skáldskaparmál. Tradução de AVELAR, Artur. Editora Barbudânia, 2014. Disponível em: Kindle. Acesso em: jul./2015.

Gylfaginning. Tradução de MOREIRA, Marcio Alessandro. Blog Nibelung’s Alliance. 2008. Acesso em: jun./2015.

. Skáldskaparmál. Tradução de MOREIRA, Marcio Alessandro. Blog Nibelung’s Alliance. 2009. Acesso em: jul./2015.

. Nafnapulur. Tradução de MOREIRA, Marcio Alessandro. Blog Nibelung's Alliance. 2009. Acesso em: jul./2015.

. Edda em prosa: Prólogo e Gylfaginning. Tradução de MOREIRA, Marcio Alessandro. 2008, 2013. Arquivo eletrônico pessoal concedido em 2015.

. Skáldskaparmál. Tradução de MOREIRA, Marcio Alessandro. 2009, 2010, 2011, 2013. Arquivo eletrônico pessoal concedido em 2015.

Nafnapulur. Tradução de MOREIRA, Marcio Alessandro. 2009, 2013. Arquivo eletrônico pessoal concedido em 2015.

. The Prose Edda: tales from Norse mythology. Tradução de YOUNG, J. I. California: University of California Press, 1954.

VENUTI, Lawrence. The Translator's Invisibility: A History of Translation. London/New York: Routledge, 1995. 